\title{
Boş Zaman Aktivitelerine Katılım ile Algılanan Wellness (Esenlik) İlişkisi ${ }^{1}$
}

DOI: 10.26466/opus.897041

\author{
Özlem Gürsoy * - Halise Dilek Sevin ** \\ * Yl. Öğr., Hacı Bayram Veli Üniversitesi, Lisansüstü Eğitim Ensitüsü, Ankara/Türkiye \\ E-Posta: ozlemgursoy83@gmail.com \\ ORCID: 0000-0003-4477-2830 \\ ** Doç. Dr., Hacı Bayram Veli Üniversitesi, Turizm Fakültesi, Ankara/Türkiye \\ E-Posta: halise.sevin@hbv.edu.tr \\ ORCID: $0000-0003-2424-1098$
}

Öz

Araştırma, üniversite son sını ve üniversiteden mezun olan öğrencilerin boş zamanların nasıl değerlendirdikleri, boş zaman aktivitelerine katılımı ile wellness arasındaki ilişkinin tespit edilmesi ve öğrencilerin wellness boyutlarına iliçkin algilarının ortaya konulması amacıyla hazırlanmıştır.Araştırmanın örneklemini, Ankara Çankaya'da KPSS-A Grubu kapsamında kurs veren toplam 13 eğitim kurumunda kayıtll 3.298 öğrenci içinden 516 öğrenci oluşturmaktadır.Araştırmada veri toplama aracı olarak, kişisel bilgi formu, Cheng-Yu Tsai (2004) tarafindan geliştirilen "Boş Zaman Katıllm Ölçeği" ile Adams, Bezner ve Steinhardt (1997) tarafindan geliştirilen ve Memnun (2006) tarafindan Türkçe'ye uyarlanan "Alg̨lanan Esenlik Ölçeği" kullanılmıştır. Verilerin değerlendirilmesinde t testi, One-Way ANOVA testi, pearson korelasyon testi ve regresyon testi kullanılmıştır. Bu çalışmada elde edilen bulgulara göre algilanan wellness ile boş zaman katıllmmn demografik değişkenlerden cinsiyet, medeni durum, yaş, yaşanılan yer, ögrrenim durumu, aylik toplam bütçe, kendine ayrlan süre ve haftalık sahip olunan boş zaman süresine göre anlaml farkllik bulunmaktadır $(p<0,05)$. Pearson korelasyon testi sonuçlarina göre, sosyal wellness ile spor aktiviteleri arasinda negatif yönlü zayıf bir ilişki $(r=-0,139)$ tespit edilirken, diğer düzeyler arasında pozitif ilişki bulunmaktadır.

Anahtar Kelimeler: Boş Zaman, Rekreasyon, Aktivite, Wellness, Algilanan Wellness.

\footnotetext{
${ }^{1}$ Bu makale Doç. Dr. H. Dilek SEViN'in danışmanlığında Özlem GÜRSOY'un Gazi Üniversitesi Sosyal Bilimler Enstitüsü Rekreasyon Yönetimi'nde hazırladığı tezden üretilmiştir.
} 


\title{
The Relationship between Leisure Activities Participation and Perceived Wellness
}

\begin{abstract}
The study was conducted to determine how senior and graduate students treat their leisure, the relationship between their participation in leisure activities and wellness and their perceptions regarding their wellness dimensions. The sample consisted of 516 students among 3298 students registered in 13 educational institutions offering courses within the scope of the KPSS-A Group in Çankaya, Ankara. The personal information form, "Leisure Participation Scale" developed by Cheng-Yu Tsai (2004) and "Perceived Wellness Scale" developed by Adams, Bezner and Steinhardt (1997) and adapted to Turkish by Memnun (2006) were used as the data collection tools. T test, One-Way ANOVA test, Pearson correlation test and regression test were used to evaluate the data. According to the findings obtained in this study, there is a significant difference between the demographic variables of perceived wellness and leisure time participation according to gender, marital status, age, place of residence, education level, monthly total budget, time allocated to oneself and weekly leisure time $(p<0,05)$. According to the results of the Pearson correlation test, a weak negative correlation $(r=-0.139)$ was found between social wellness and sports activities, while there was a positive correlation between other levels.
\end{abstract}

Key Words: $\quad$ Leisure, Recreation, Activity, Wellness, Perceived Wellness. 


\section{Giriş}

Zaman; bir eylemin içinde geçtiği, geçeceği ya da geçmekte olduğu süredir. (Türkçe Sözlük, 1983, s.1340). Marshall'a göre, zaman, genel olarak "fiziksel" ve "toplumsal" zaman olarak ikiye ayrlarak incelenmektedir. Fiziksel zaman; biyolojik ve ay hareketleri, med-cezir ve benzeri olayları içeren bir zaman dilimidir. Toplumsal zaman ise, zamana anlam katmak, etrafında örgütlenmiş insan faaliyetlerinin doğası, kuruluşu ve sonuçlaryyla ilintilidir (Marshall, 1999, s.689).

Zaman, kullanım açısından, çalışma zamanı ve çalışma dışı zaman olarak iki grupta ele alınabilir. Çalışma zamanı, temelde bireyin para kazanmak ve geçimi sağlamak için iş yerinde geçirdiği zamandan oluşmaktadır. Çalışma dışı zaman ise insanın yaşamını idame ettirmesi için gerekli olan temel fizyolojik ihtiyaçlardan beslenme ve uykuya ayırdığ 1 zaman ve boş zamandan oluşmaktadır (Karaküçük, 1999).

Günlük yaşamda oldukça sık kullanılan, ancak gerçek içeriğinin bilimsel bir temelde ortaya konmasının, bu sık kullanım içinde pek olanaklı olmadığı̆, dolayısıyla yanlış ya da eksik yorumlanan kavramlardan birisi de "boş zaman" kavramıdır. Boş zaman olgusunun ilk ortaya çıkışı, insanların yerleşik düzene geçip düzenli iş hayatlarına sahip olmalarına dayandırılmaktadır. Boş zaman kavramının gelişim süreci literatürde, endüstriyel dönem öncesi ve sonrası olarak iki aşamalı olarak incelenmektedir (Bull, Hoose ve Wheet, 2003, s.73). Boş zaman kavram1, etimolojik açıdan Yunanca "skhole" ve Latince "licere" kelimelerinin birleşiminden oluşmuş olup, İngilizce "leisure" kelimesi ile ifade edilir. Yunanca skhole kelimesi, iş dişı, zorunluluklardan muaf olma anlamında öğrenme ve kültür ile ilişkili iken Latince licere kelimesi, genelde izinli olmak ya da özgür olmak anlamlarına gelir (Blackshaw, 2010, s.4-5).

Veblen boş zamanı, "zamanın üretimsel olmayan tüketimi" olarak tanımlamıştır (Veblen, 1995, s.38). Bazı kuramcılar, boş zamanın biri dar diğeri geniş olmak üzere iki anlamından söz ederler. Onlara göre, dar anlamda boş zaman, kişinin iş ile ilgili yükümlülüklerinden ya da diğer mecburi görevlerinden serbest olduğu, mecburiyet içermeyen bir zaman dilimidir. Geniş anlamda ise, kişilerin düzenli olarak sorumlulukları dışında, hoşlandıkları, kendilerine haz veren faaliyetlerle uğraşmalarını ifade eder. Kişinin kendisini geliştirmesi, kendini ifade etmesi ve haz 
duymak gayesiyle fiziksel, kültürel ve sosyal etkinliklerde serbestçe bulunma hak ve fırsatlarına sahip olması olarak görülür (Türkkahraman, 2006, s.240).

Boş zamanları aktif ve etkin değerlendirmek kişilere ve topluma büyük ölçüde katkı sağlamaktadır. Fiziki sağlığı geliştirir, ruh sağlığını korur ve sürdürülmesine katkı sağlar, insanı sosyalleştirir, bireysel beceri ve yeteneğin gelişmesini sağlar, yaratıcı gücü geliştirir, insanı mutlu eder, çalışma başarısı ve iş verimini arttırır, ekonomik hareketi geliştirir, toplumsal dayanışma ve bütünleşmeyi sağlar, demokratik toplumun yaratılmasına imkan sağlar, yaşam kalitesini arttırır, eğitimsel açıdan yarar sağlar, heyecan ve macera ihtiyacını giderir, duygusal gereksinimi giderir (Ardahan ve diğ, 2016: 11; Karaküçük, 2008, s.66; Karaküçük ve Akgül, 2016). Ayrıca boş zaman bireyin ailesiyle uyumlu ilişkiler geliştirmesine yardımcı olur (Sevin ve Barakazı, 2019, s.303). Boş zamanın değerlendirilmesi, pozitif psikoloji ve iyi oluş (wellbeing) ile yakından ilişkilidir ve boş zaman etkinliklerine katılım mutluluk ve sağlık üzerine olumlu katkı sağlamaktadır.

Egzersiz ve sosyalleşme içeren boş zaman aktivitelerine katılım ise, sağlıklı yaşlanma, fiziksel sağlık ve esenlik gibi bileşenlerle ilişkilidir. (Karaküçük, 2016, s.562-563). Bu bağlamda TDK'ya göreesenlik; "esen olma durumu, sağlık, afiyet, sıhhat, selamet, hastalık karşıtı" olarak tanımlanmaktadır. İngilizcede "wellness" olarak kullanılan, Türkçede zindelik, fiziksel uyum (fitness), iyi oluş hali anlamlarına karşlık gelen bu farklı kavramlar "esenlik" olarak Türkçeleştirmiş ve yapılan çoğu çalışmalarda bu şekilde kullanılmıştır (Karagözoğlu, 2005, s.10).

Dunn, esenliği Dünya Sağlık Örgütü’ nün sağlık tanımına göre “esenlik, fiziksel ve psikolojik esenliği geliştirmeyi sürdürme çabası için bir yaşam sürecidir" şeklinde ifade etmiş ve tarafınca 1961 yılında yayınlanan 'High Level Wellness'adlı kitabında "wellness" ifadesini literatürde ilk olarak, "kişinin sahip olduğu potansiyeli en üst düzeye çıkarmaya odaklı, bütünleşik bir işleyiş yöntemi" olarak tanımlamıştır. Alman sağlık pedagogu olan Haug wellnessi, sağlığın uygulama odaklı ve pragmatik yeni bir anlayışı olarak görmekte ve her ferdin yaşam kalitesini merkeze oturtmaktadır (Haug, 1991, s.428).

Wellness kavramının öncülerinden bir diğeri de Bill Hettler'dir. Hettler wellness alanındaki çalışmalarına Wiscounsin Üniversitesi'nde baş- 
lamıştır.Amacı esen bir kampüs yaratmaktır.Hettler'e göre wellness; kişinin daha başarılı bir varoluş için gerekli olan seçimlerin farkına vardığ 1 ve bu seçimleri yaptığ 1 aktif bir süreç olarak tanımlanır. Birey böylelikle kendi sağlığının sorumluluğunu üslenmiş olmaktadır (Steward, 1998, s.472-489).

Adams, Bezner ve Steinhardt (1997) tarafından geliştirilen algılanan wellness modeli, bireylerin optimal wellnes'a nasıl ulaşabileceklerine dair bütünsel bir kavramsallaştırma sağlar. Adams ve arkadaşları wellness'ı insan varlığının fiziksel, manevi, psikolojik, sosyal, duygusal ve entelektüel boyutlarının tutarlı ve dengeli gelişimine izin veren bir yaşam biçimi olarak tanımlamaktadır. Fiziksel boyut; kişinin fiziksel sağlığı ile ilgili olumlu alg1 ve beklentilerini kapsar. Duygusal boyut; kişinin özgüvenini yani benlik saygısını temsil eder. Psikolojik boyut; bireyin iyimserliği ve yaşamla ilgili olumlu beklentileridir. Sosyal boyut; kişinin sosyal hizmet sağlayıcısı ile aynı zamanda sosyal destek alması ile karakterize edilir. Ruhsal boyut; yaşamın anlamı ile ilgili olumlu algılar ve bir amaç sahibi olarak yaşama çabasıdır. Son olarak, entelektüel boyut; zihinsel aktiviteyi uyaracak düzey deoptimal entelektüel eylemliliğe sahip olmak şeklinde tanımlanabilir (Adams ve ark., 1997).

Algılanan wellness, insanların kendi sağlıkları hakkında sahip oldukları fikirdir. Bu fikir genellikle kişinin sağlığı hakkında gerçeği ifade eden bir betimlemeden ziyade kişinin kendisini nasıl bulduğu (sağlıklı veya sağlıksız) ile alakalı bir görüştür (Tsai, 2004). Fiziksel iyilik, sosyal etk,leşimler, ruhsal ve duygusal kapasite ve manevi durum gibi yaşamın bütün boyutlarıyla ilgili bir kavramdır. Algılanan wellness, genel sağlık seviyesini göstermekle birlikte, kişi için ihtiyaçları da ortaya koymaktadir (Kim, Oh, Kim, Kim, Lee ve Ha, 2014).

Lenfelder (1987), Zimmer ve Lin (1996) tarafından yapılan araştırmalarda, boş zamanı etkili olarak değerlendirmenin wellness ve ruh sağlığı üzerinde olumlu etkilerinin olduğu; Richards, Hardy ve Wadsworth (2003), sosyal, fiziksel ve entelektüel etkinliklerin bilişsel performansı artıracağı, yaşa bağlı bilişsel gerileme oranını yavaşlatacağı, fiziksel egzersiz ve boş zaman aktivitesinin, ileri yaştaki bireylerin hafızası üzerinde olumlu etkiye sahip olduğunu; Chandler, Holden ve Kolander (1992), günlük yaşamın baskısı ve sıkıntıları nedeniyle hayatlarının ruhsal boyutlarını göz ardı etmiş insanların, boş zamanlarını, duyarlılık ka- 
zanma ya da ruhsal yenilenme aracı olarak kullanabileceğini ifade etmişlerdir.

\section{Araştırmanın Amacı}

Çalışma kapsamında, üniversite son sınıf ve üniversiteden mezun olan öğrencilerin boş zamanlarını nasıl değerlendirdikleri, boş zaman aktivitelerine katılımı ile wellness arasındaki ilişkinin tespit edilmesi ve öğrencilerin wellness boyutlarına ilişkin algılarının ortaya konulması araştırmanın temel amacını oluşturmaktadır.

Alanyazındaki araştırmalar incelendiğinde, üniversite öğrencilerinin boş zaman faaliyetlerine yönelik tutumları, boş zaman ve rekreaktif etkinliklere katılım alışkanlıkları, iyilik hali boyutlarına göre özyeterlilik ve sürekli öfkeleri arasındaki ilişki, iyilik hali ve özgecilik arasındaki ilişki gibi konular üzerinde durulmuştur. Boş zaman aktivitelerine katılım ile algılanan wellness'ın alt boyutları arasındaki ilişkiyi inceleyen araştırmaların az olması nedeniyle araştırma bu alandaki bilgi birikimine katkıda bulunacağı yönünde önem arz etmektedir.

Araştırmanın hipotezleri şu şekildedir:

H1: Boş zaman aktivitelerine katılım düzeyleri demografik özelliklere göre farkl1lık göstermektedir.

H2: Algılanan wellness düzeyleri demografik özelliklere göre farklılık göstermektedir.

H3: Boş zaman aktivitelerine katılım düzeyleri ile algılanan wellness düzeyleri arasında ilişki vardır.

\section{Yöntem}

Araştırmanın Örneklemi: Tesadüfi örnekleme yöntemine dayanarak oluşturulmuştur. Tesadüfi örnekleme yöntemi, evren içindeki tüm birimlerin örnekleme seçilme şanslarının eşit ve bağımsız olduğu örnekleme yöntemidir. Bu özelliğinden dolayı, evreni temsil etme gücü yüksektir. Örneklemeden elde edilen sonuçlar, evrene genellenebilir. Yapılan seçme işlemi tesadüfi olduğundan yanlılık ve seçmeye dayalı örnekleme hatasının en az düzeyde olması beklenir. Örnekleme hatasını hesaplamak mümkündür. (Baştürk ve Taştepe, 2013). 
Araştırmanın evrenini, Ankara ili Çankaya ilçe bazında KPSS-A Grubu kapsamında kurs veren toplam 13 eğitim kurumunda kayıtlı 3.298 öğrenci mevcuttur. Yapılan örneklem hesabına göre en az 344 öğrenciye anket yapılması yeterlidir. Ancak, hata payını aza indirgemek ve güvenirlik seviyesini arttırmak amacıyla 516 öğrenci örneklem grubu olarak belirlenmiştir. Veri toplama sürecinden önce ilgili üniversite etik kurulundan gerekli izinler alınmıştır. Bu çalışmanın etik açıdan bir sakınca taşımadığı Ankara Hacı Bayram Veli Üniversitesi Etik Komisyonu'nun almış olduğu 05.09.2018 tarih ve E.5445 sayılı karar ile tespit edilmiştir. Çalışmanın yürütlebilmesi araştırmanın yapılacağı eğitim kurumlarından yazılı onay alınmıştır. Araştırmaya katılımda öğrencilerin gönüllülükleri esas alınmış, çalışmadan çekilme hakları saklı kalmıştır.

Veri Toplama Tekniği: Araştırmada veri toplama aracı olarak, kişisel bilgi formu, öğrencilerin rekreasyon aktiviteleri ve aktivitelere katılım sıklığını tespit etmek amacıyla Cheng-YuTsai (2004) tarafından geliştirilen "Boş Zaman Katılım Ölçeği” anketinden yararlanılmış ve Adams, Bezner ve Steinhardt (1997) tarafından geliştirilen "Perceived Wellness Scale" Türkçe uyarlaması güvenirlik ve geçerlik çalışması Memnun (2006) tarafından yapılan “Algılanan Esenlik Ölçeği” kullanılmıştır.

Güvenirlik Analizi: Açık alan aktiviteleri için yapılan faktör analizinde KMO değeri 0,762 olarak hesaplanmıştır. Buna göre örneklem sayısı faktör analizi için uygundur (KMO>0,500). Bartlett testi kapsamında $X^{2}$ değeri 658,710 ve istatistiksel olarak anlamlı bulunmuştur $(p<0,05)$. KMO ve Bartlett testi sonucuna göre verilerin faktör analizi için uygun olduğu sonucuna ulaşılmıştır. Yapılan faktör analizi sonucuna göre ölçeğin faktör yükleri 0,444 ile 0,667 arasında değişen 7 madde ve tek boyuttan oluştuğu belirlenmiştir. Ölçeğin toplam varyansı açıklama oranı \%38,709; güvenirlik katsayısı 0,723'tür. Buna göre boyutun güvenirlik düzeyi oldukça yüksektir. Spor etkinlikleri için yapılan faktör analizinde KMO değeri 0,864 olarak hesaplanmıştır. Buna göre örneklem sayısı faktör analizi için uygundur (KMO>0,500). Bartlett testi kapsamında $X^{2}$ değeri 1769,794 ve istatistiksel olarak anlamlı bulunmuştur $(p<0,05)$. KMO ve Bartlett testi sonucuna göre verilerin faktör analizi için uygun olduğu sonucuna ulaşılmıştır. Yapılan faktör analizi sonucuna göre ölçeğin fak- 
tör yükleri 0,497 ile 0,701 arasında değişen 12 madde ve tek boyuttan oluştuğu belirlenmiştir. Ölçeğin toplam varyansı açılama oranı $\% 36,839$; güvenirlik katsayısı 0,830'dur. Buna göre boyutun güvenirlik düzeyi çok yüksektir. Hobiler ve açık alan aktiviteleri için yapılan faktör analizinde KMO değeri 0,818 olarak hesaplanmıştır. Buna göre örneklem sayısı faktör analizi için uygundur $(\mathrm{KMO}>0,500)$. Bartlett testi kapsamında $X^{2}$ değeri 1059,358 ve istatistiksel olarak anlamlı bulunmuştur $(p<0,05)$. KMO ve Bartlett testi sonucuna göre verilerin faktör analizi için uygun olduğu sonucuna ulaşılmıştır. Yapılan faktör analizi sonucuna göre ölçeğin faktör yükleri 0,395 ile 0,716 arasında değişen 11 madde ve tek boyuttan oluştuğu belirlenmiştir. Faktör yükünün 0,300'den küçük olması nedeniyle 'çay yapmak' maddesi analize dahil edilmemiştir. Ölçeğin toplam varyansı açıklama oranı \%30,884; güvenirlik katsayısı 0,747'dir. Buna göre boyutun güvenirlik düzeyi oldukça yüksektir. Kültürel eğlence aktiviteleri için yapılan faktör analizinde KMO değeri 0,766 olarak hesaplanmıştır. Buna göre örneklem sayısı faktör analizi için uygundur $(\mathrm{KMO}>0,500)$. Bartlett testi kapsamında $X^{2}$ değeri 582,848ve istatistiksel olarak anlamlı bulunmuştur $(\mathrm{p}<0,05)$. KMO ve Bartlett testi sonucuna göre verilerin faktör analizi için uygun olduğu sonucuna ulaşılmıştır. Yapılan faktör analizi sonucuna göre ölçeğin faktör yükleri 0,405 ile 0,799 arasında değişen 5 madde ve tek boyuttan oluştuğu belirlenmiştir. Faktör yükünün 0,300 ' den küçük olması nedeniyle 'televizyon seyretmek' maddesi analize dahil edilmemiştir. Ölçeğin toplam varyansı açıklama oranı \%49,691; güvenirlik katsayısı 0,696'dır. Buna göre boyutun güvenirlik düzeyi oldukça yüksektir. Ev merkezli sosyal aktiviteler için yapılan faktör analizinde KMO değeri 0,738 olarak hesaplanmıştır. Buna göre örneklem sayısı faktör analizi için uygundur $(\mathrm{KMO}>0,500)$. Bartlett testi kapsaminda $\mathrm{X}^{2}$ değeri 564,365 ve istatistiksel olarak anlamlı bulunmuştur $(\mathrm{p}<0,05)$. KMO ve Bartlett testi sonucuna göre verilerin faktör analizi için uygun olduğu sonucuna ulaşılmıştır. Yapılan faktör analizi sonucuna göre ölçeğin faktör yükleri 0,493 ile 0,747 arasında değişen 6 madde ve tek boyuttanoluştuğu belirlenmiştir. Ölçeğin toplam varyansı açıklama oranı \%41,376; güvenirlik katsayısı 0,700'dır. Buna göre boyutun güvenirlik düzeyi oldukça yüksektir. Sosyal aktiviteler için yapılanfaktör analizinde KMO değeri 0,783 olarak hesaplanmıştır. Buna göre örneklem sayısı faktör analizi için uygundur 
(KMO>0,500). Bartlett testi kapsamında $X^{2}$ değeri 1040,357 ve istatistiksel olarak anlamlı bulunmuştur $(\mathrm{p}<0,05)$. KMO ve Bartlett testi sonucuna göre verilerin faktör analizi için uygun olduğu sonucuna ulaşılmıştır. Yapılan faktör analizi sonucuna göre ölçeğin faktör yükleri 0,640 ile 0,919 arasında değişen 4 madde ve tek boyuttan oluştuğu belirlenmiştir. Ölçeğin toplam varyansı açıklama oranı \%69,038; güvenirlik katsayısı 0,834 'tür. Buna göre boyutun güvenirlik düzeyi çok yüksektir.

\section{Tablo 1.Algılanan Esenlik ölçeğine Ait Güvenirlik Katsayılan}

\begin{tabular}{lc}
\hline & Güvenirlik Katsayısı \\
\hline Psikolojik Wellnes & 0,40 \\
Duygusal Wellnes & 0,67 \\
Sosyal Wellnes & 0,58 \\
Fiziksel Wellnes & 0,66 \\
Manevi Wellnes & 0,70 \\
Entelektüel Wellnes & 0,47 \\
\hline
\end{tabular}

Algilanan Esenlik ölçeği duygusal wellness, fiziksel wellness ve manevi wellness boyutlarının güvenirlikleri oldukça yüksektir. Psikolojik wellness, sosyal wellness ve entelektüel wellness boyutlarının güvenirlikleri düşüktür.

Tablo 2.Ölçek Puanlarına Ait Betimsel İstatistikler ve Normallik Testi

\begin{tabular}{llcccccc}
\hline & n & Minimum & Maximum & Ortalama & ss & Çarpıklık & Basıklık \\
\hline Psikolojik Wellness & 116 & 1,50 & 6,00 & 3,79 & 0,70 &, 072 &, 108 \\
Duygusal Wellness & 516 & 1,67 & 6,00 & 4,07 & 0,87 &,- 093 &,- 404 \\
Sosyal Wellness & 516 & 1,83 & 6,00 & 4,41 & 0,82 &,- 202 &,- 590 \\
Fiziksel Wellness & 516 & 1,00 & 6,00 & 3,77 & 0,84 &,- 119 &, 236 \\
Manevi Wellness & 516 & 1,00 & 6,00 & 4,04 & 0,92 &,- 278 &,- 161 \\
Entelektüel Wellness & 516 & 1,50 & 6,00 & 3,91 & 0,69 &,- 094 &, 606 \\
\hline Açı Alan Aktiviteleri & 516 & 1,00 & 5,00 & 2,25 & 0,57 &, 814 & 1,903 \\
Spor Aktiviteleri & 516 & 1,00 & 4,00 & 1,81 & 0,57 & 1,336 & 2,523 \\
Hobiler ve Açık Alan & 516 & 1,00 & 5,00 & 2,25 & 0,61 &, 833 & 1,464 \\
Aktiviteleri & & & & & & & \\
Kültürel Eğlence & 516 & 1,00 & 5,00 & 2,39 & 0,74 &, 522 &, 534 \\
Aktiviteleri & & & & & & & \\
Ev Merkezli Sosyal & 516 & 1,00 & 5,00 & 3,19 & 0,68 &,- 522 & 1,412 \\
$\begin{array}{l}\text { Aktiviteler } \\
\text { Sosyal Aktiviteler }\end{array}$ & 516 & 1,00 & 5,00 & 2,00 & 0,88 & 1,160 & 1,293 \\
\hline
\end{tabular}

Algılanan wellness ve boş zaman katılım ölçeği boyut puanlarının çarpıklık ve basıklık değerleri -3 ile +3 arasında olduğundan normallik sağlanmış olup analizlerinde parametrik olan test teknikleri kullanılmış- 
tır. Spor etkinlikleri boyutu için normalliği bozarak uç değer olan bir veri analize dahil edilmemiştir.

\section{Bulgular ve Yorum}

Araştırmaya katılan öğrencilerin demografik özellikleri incelendiğinde, cinsiyet durumlarına göre 516 öğrencinin 292'si (\%56,6 oranında) kadın, 224 'ünü (\%43,4 oranında) ise erkek öğrencilerden oluştuğu; medeni durumlarına göre dağılımları incelendiğinde, çoğunluğun 483'ünün (\%93,6 oranında) bekar, 33'ünün (\%6,4 oranında) evli öğrencilerden oluştuğu; yaş gruplarına göre dağılımları incelendiğinde, 221'i (\%42,8 oranında) 21-23 yaş, 204'ü (\%39,5 oranında) $24-26$ yaş ve $91^{\prime} i$ (\%17,6 oranında) 27 ve üzeri yaşta oldukları; yaşamlarının büyük bölümünü nerede geçirdiklerine dair incelemede, 31'i (\%6,0 oranında) köy-kasaba, 81'i (\%15,7 oranında) ilçe, 191'i (\%37,0 oranında) il ve 213'ü (\%41,3 oranında) büyükşehirde geçirdikleri; öğrenim durumları incelendiğinde, 162'i (\%31,4 oranında) son sınıf ve 354'ü (\%68,6 oranında) mezun olduğu; gelir durumu verileri incelendiğinde, çoğunluğun 282 'sinin (\%54,7 oranında) 250-750 TL, 90'ının (\%17,4 oranında) 751 - $1250 \mathrm{TL}, 40$ 'ının (\%7,8 oranında) 1251 - 1750 TL ve 104'ünün $(\% 20,2) 1751$ TL gelir düzeyine sahip olduğu; günlük yapmakla zorunlu oldukları işler dışında öğrencilerin kendilerine ayırdıkları süre dilimleri incelendiğinde, 36'sı (\%7,0 oranında) hiç kalmiyor, 176's1 (\%34,1 oranında) 1-2 saat, 196's1 (\%38,0 oranında) 3-4 saat, 70'i (\%13,6 oranında) 5-6 saat ve 38'i (\%7,4 oranında) 7 saat ve üzeri zaman ayırabildikleri; haftalık sahip olduğu boş zaman süresi incelendiğinde, ayrılan boş zaman süresinin 222'sinin (\%43, oranında) yetersiz, 154 'ünün (\%29,8 oranında) normal ve 140 '1nın (\%27,1 oranında) yeterli olduğu tespit edilmiştir.

Tablo 3.Algılanan Wellness ve Boş Zaman Katılımın Cinsiyet Açısından İncelenmesi

\begin{tabular}{lllllll}
\hline Cinsiyetiniz? & & n & Ortalama & ss & t & p \\
\hline \multirow{2}{*}{ Psikolojik Wellness } & kadın & 292 & 3,77 & 0,70 &,- 845 & \multirow{2}{*}{, 399} \\
& erkek & 224 & 3,82 & 0,69 & & \\
Duygusal Wellness & kadın & 292 & 3,97 & 0,90 & \multirow{2}{*}{$-2,733$} & \multirow{2}{*}{$006^{*}$} \\
& erkek & 224 & 4,18 & 0,81 & & \\
Sosyal Wellness & kadın & 292 & 4,44 & 0,81 & \multirow{2}{*}{, 920} & \multirow{2}{*}{358} \\
& erkek & 224 & 4,37 & 0,84 & & \\
Fiziksel Wellness & kadın & 292 & 3,66 & 0,81 & \multirow{2}{*}{$, 3,540$} & \multirow{2}{*}{$000^{*}$}
\end{tabular}




\begin{tabular}{|c|c|c|c|c|c|c|}
\hline \multirow{2}{*}{ Manevi Wellness } & kadın & 292 & 3,95 & 0,89 & \multirow{2}{*}{$-2,500$} & \multirow{2}{*}{, $013^{*}$} \\
\hline & erkek & 224 & 4,15 & 0,94 & & \\
\hline \multirow{2}{*}{ Entelektüel Wellness } & kadın & 292 & 3,89 & 0,69 & \multirow{2}{*}{,- 631} & \multirow{2}{*}{, 528} \\
\hline & erkek & 224 & 3,93 & 0,69 & & \\
\hline \multirow{2}{*}{ Açık Alan Aktiviteleri } & kadın & 292 & 2,20 & 0,55 & \multirow{2}{*}{$-2,579$} & \multirow{2}{*}{, $010^{*}$} \\
\hline & erkek & 224 & 2,33 & 0,60 & & \\
\hline \multirow{2}{*}{ Spor Aktiviteleri } & kadın & 292 & 1,75 & 0,56 & \multirow{2}{*}{$-2,450$} & \multirow{2}{*}{, $015^{*}$} \\
\hline & erkek & 224 & 1,88 & 0,57 & & \\
\hline \multirow{2}{*}{ Hobiler ve Açık Alan Aktiviteleri } & kadın & 292 & 2,33 & 0,64 & \multirow{2}{*}{3,742} & \multirow{2}{*}{, $000^{*}$} \\
\hline & erkek & 224 & 2,13 & 0,54 & & \\
\hline \multirow{2}{*}{ Kültürel Eğlence Aktiviteleri } & kadın & 292 & 2,48 & 0,75 & \multirow{2}{*}{3,226} & \multirow{2}{*}{, $001^{*}$} \\
\hline & erkek & 224 & 2,27 & 0,70 & & \\
\hline \multirow{2}{*}{ Ev Merkezli Sosyal Aktiviteler } & kadın & 292 & 3,20 & 0,65 & \multirow{2}{*}{,381 } & \multirow{2}{*}{,704 } \\
\hline & erkek & 224 & 3,18 & 0,71 & & \\
\hline \multirow{2}{*}{ Sosyal Aktiviteler } & kadın & 292 & 1,91 & 0,83 & \multirow{2}{*}{$-2,729$} & \multirow{2}{*}{, $007^{*}$} \\
\hline & erkek & 224 & 2,13 & 0,93 & & \\
\hline
\end{tabular}

${ }^{*} p<0,05$

Öğrencilerin cinsiyet durumlarına göre boş zaman katılım düzeyleri incelendiğinde, açık alan aktivitelerine, spor aktivitelerine, hobiler ve açık alan aktivitelerine, kültürel eğlence aktivitelerine, sosyal aktivitelere katılımda anlamlı farklılık saptanmıştır $(\mathrm{p}<0,05)$ Ortalama puanlar incelendiğinde erkeklerde açık alan aktiviteleri, spor aktiviteleri ve sosyal aktivitelere katılım düzeylerinin, kadınlarda ise hobiler ve açık alan aktiviteleri ile kültürel eğlence aktivitelerine katılım düzeyleri daha büyük olduğu tespit edilmiştir. Öğrencilerin cinsiyet durumlarına göre algılanan wellness düzeyleri incelendiğinde, duygusal, fiziksel ve manevi wellness alt boyutlarında anlamlı farklılık bulunmaktadır $(\mathrm{p}<0,05)$. Ortalama puanlar incelendiğinde erkeklerin duygusal, fiziksel ve manevi wellness düzeyleri daha büyük olduğu tespit edilmiştir.

Öğrencilerin boş zaman aktivitelerine katılımlarını etkileyen faktörlerden birisi cinsiyetttir. Süzer (2000), üniversite öğrencilerinin boş zamanlarını değerlendirme üzerine yaptığı çalışmasında, erkek öğrencilerin kız öğrencilere oranla sprotif faaliyetlere daha aktif olarak katıldıklarını tespit etmiştir. Ergül (2008), üniversite gençliğinin sportif rekreasyon etkinliklerine yönelik ilgileri ve katılım düzeyleri üzerine yaptığı çalışmasında ise erkek öğrencilerin kadın öğrencilere göre spor yapmaya daha eğimli oldukları tespit edilmiştir. Bu bağlamda birçok fiziksel aktivitenin kadınlar tarafından tercih edilememesinin temel sebepleri arasinda, fiziksel yapılarının erkeklerin fiziksel yapısından daha zayıf olması, boş zaman aktivitelerine katılım için ailelerinden yeterli desteği ala- 
mamaları ve yeterli boş zamanlarının olmaması olarak sıralanabilir. Uysal (2003) ve Mehmedoğlu'nun (2004) çalışmalarında dindarlığın ibadet, etki ve tecrübe boyutlarında erkeklerin lehine anlamlı bir farklılık bulunmuştur. Çakıcı'nın (2010), esenlik ve akademik tükenmişlik ilişkisini değerlendirdiği çalışmasında Şimşek ve arkadaşlarının (2012), tıp fakültesi öğrencilerinde sağlıklı yaşam biçimi davranşları ve ilişki etmenleri değerlendirdikleri çalışmasında; Kafkas ve arkadaşlarının (2012), beden eğitimi öğretmenlerinin sağlıklı yaşam biçimi davranış düzeylerini incelediği çalışmasında, erkeklerin kadınlara göre anlamlı şekilde daha yüksek wellness puanına sahip olduklarını tespit etmiştir.

Tablo 4. Algılanan Wellness ve Boş Zaman Katılımın Medeni Durum Açısından Incelenmesi

\begin{tabular}{|c|c|c|c|c|c|c|}
\hline \multirow{3}{*}{$\begin{array}{l}\text { Medeni durumunuz? } \\
\text { Psikolojik Wellness }\end{array}$} & \multirow{3}{*}{$\begin{array}{l}\mathbf{n} \\
\text { bekar } \\
\text { evli }\end{array}$} & \multicolumn{2}{|c|}{ Ortalama } & \multirow{3}{*}{$\begin{array}{r}\text { ss } \\
0,71 \\
0,47\end{array}$} & \multirow{3}{*}{$\begin{array}{r}\mathbf{t} \\
733\end{array}$} & \multirow{3}{*}{$\begin{array}{r}\mathbf{P} \\
, 464\end{array}$} \\
\hline & & 483 & 3,79 & & & \\
\hline & & 33 & 3,70 & & & \\
\hline \multirow{2}{*}{ Duygusal Wellness } & bekar & 483 & 4,05 & 0,88 & \multirow{2}{*}{$-1,525$} & \multirow[b]{2}{*}{,128 } \\
\hline & evli & 33 & 4,29 & 0,66 & & \\
\hline \multirow{2}{*}{ Sosyal Wellness } & bekar & 483 & 4,40 & 0,83 & \multirow{2}{*}{,- 822} & \multirow[b]{2}{*}{,412 } \\
\hline & evli & 33 & 4,52 & 0,75 & & \\
\hline \multirow{2}{*}{ Fiziksel Wellness } & bekar & 483 & 3,77 & 0,84 & \multirow{2}{*}{,- 416} & \multirow{2}{*}{ 678 } \\
\hline & evli & 33 & 3,83 & 0,84 & & \\
\hline \multirow{2}{*}{ Manevi Wellness } & bekar & 483 & 4,02 & 0,93 & \multirow{2}{*}{$-2,140$} & \multirow{2}{*}{, $033^{*}$} \\
\hline & evli & 33 & 4,37 & 0,61 & & \\
\hline \multirow{2}{*}{ Entelektüel Wellness } & bekar & 483 & 3,89 & 0,69 & \multirow{2}{*}{$-2,563$} & \multirow{2}{*}{, $011^{*}$} \\
\hline & evli & 33 & 4,21 & 0,63 & & \\
\hline \multirow{2}{*}{ Açık Alan Aktiviteleri } & bekar & 483 & 2,26 & 0,58 & \multirow{2}{*}{1,379} & \multirow{2}{*}{168} \\
\hline & evli & 33 & 2,12 & 0,50 & & \\
\hline \multirow{2}{*}{ Spor Aktiviteleri } & bekar & 483 & 1,83 & 0,58 & \multirow{2}{*}{2,855} & \multirow{2}{*}{, $004^{*}$} \\
\hline & evli & 33 & 1,54 & 0,27 & & \\
\hline \multirow{2}{*}{ Hobiler ve Açık Alan Aktiviteleri } & bekar & 483 & 2,26 & 0,62 & \multirow{2}{*}{2,499} & \multirow{2}{*}{, $016^{*}$} \\
\hline & evli & 33 & 2,09 & 0,34 & & \\
\hline \multirow{2}{*}{ Kültürel Eğlence Aktiviteleri } & bekar & 483 & 2,40 & 0,74 & \multirow{2}{*}{894} & \multirow{2}{*}{,371 } \\
\hline & evli & 33 & 2,28 & 0,65 & & \\
\hline & bekar & 483 & 3,17 & 0,68 & -2766 & $006 *$ \\
\hline Ev Merkezli Sosyal Aktiviteler & evli & 33 & 3,51 & 0,55 & $-2,766$ &, $006^{*}$ \\
\hline & bekar & 483 & 2,01 & 0,90 & & \\
\hline Sosyal Aktiviteler & evli & 33 & 1,88 & 0,64 & ,849 & ,396 \\
\hline
\end{tabular}

${ }^{*} p<0,05$

Öğrencilerin medeni durumlarına göre boş zaman katılım düzeyleri incelendiğinde, spor aktivitelerine, hobiler ve açık alan aktivitelerine, ev merkezli sosyal aktivitelere katılımda anlamlı farklılık saptanmıştır $(\mathrm{p}<0,05)$. Ortalama puanlar incelendiğinde bekar olanların spor aktivite- 
leri ile hobiler ve açık alan aktivitelerine katılım düzeyleri, evli olanların ise ev merkezli sosyal aktivitelere katılım düzeyleri daha büyük olduğu tespit edilmiştir. Öğrencilerin medeni durumlarına göre algılanan wellness düzeyleri incelendiğinde, manevi ve entelektüel wellness alt boyutlarında anlamlı farklılık bulunmaktadır $(\mathrm{p}<0,05)$. Ortalama puanlar incelendiğinde evli olanların öğrencilerin manevi ve entelektüel wellness düzeyleri daha büyük olduğu tespit edilmiştir.

Medeni durumun boş zaman aktivitelerini tercih etmede önemli bir rol oynadığını ortaya koyan birçok araştırma bulunmaktadır. Öztürk'ün (2013), sanayi çalışanlarının rekreatif aktivitelere katılımlarının örgütsel bağll1ık ve tükenmişlik düzeylerine etkisi üzerine yaptı̆̆ 1 çalışmasında, sanayi çalışanlarının medeni durumlarına göre bekâr olanlar evli olanlara göre daha fazla rekreatif etkinliklere katıldıkları; Thrane'nin (2000), erkekler, kadınlar ve boş zaman üzerine yaptığı çalışmasında, evlilikle eğlence arasında negatif bir ilişki olduğunu, çünkü evlilerin evleri için daha fazla zaman harcamakta ve evde çocuk varsa bu sürenin daha da artacağını, bekârların ise kendisine ayıracağı boş zamanın daha yüksek olduğunu tespit etmiştir. Dierksen'ın (2005), benlik algısı üzerine yaptığ1 çalışmasında, evli olan müdürlerin toplam esenlik puanlarını bekar olanlara; Memnun'un (2006), beden eğitimi öğretmenlerinin esenlik algıları üzerine yaptığı çalışmasında, duygusal esenlik boyutunu evli öğretmenlerde; Myers ve Degges-White (2007), evli olan bireylerin yaratıcılık yeteneği, sevgi düzeyi, kendini gerçekleştirme ve düşünce faktörü yönüyle evli olmayan bireylerden; Walton ve Takeuchi (2010), Asya kökenli Amerikalı kadınlar üzerine yaptığı çalışmada, evli olan kadınların iyilik düzeylerinin hiç evlenmemiş kadınlardan anlamlı derecede yüksek olduğunu belirtmiştir. İlgili alanyazın incelendiğinde, evlilerin sosyal ilişkileri geliştirme konusunda daha başarılı oldukları sonucuna ulaşılmaktadır.

Öğrencilerin yaş gruplarına göre boş zaman katılım düzeyleri incelendiğinde, spor aktivitelerine katılımda anlamlı farklılık saptanmıştır $(\mathrm{p}<0,05)$. Ortalama puanlar incelendiğinde $24-26$ yaş arası olanların puan ortalaması en büyük iken 27 yaş ve üzeri olanların ortalaması en küçüktür. Öğrencilerin yaş gruplarına göre algılanan wellness düzeyleri incelendiğinde, fiziksel ve entelektüel wellness alt boyutlarında anlamlı farklılık bulunmaktadır $(\mathrm{p}<0,05)$. Ortalama puanlar incelendiğinde 27 yaş ve 
üzeri olanların puan ortalaması en büyük iken yaş azaldıkça ortalama da azalmaktadır.

Tablo 5. Algılanan Wellness ve Boş Zaman Katılımın Yaş Açısından Incelenmesi

\begin{tabular}{|c|c|c|c|c|c|c|c|}
\hline Yaşınız? & $\mathbf{n}$ & & Ortalama & ss & $\mathrm{f}$ & p & $\begin{array}{c}\text { Çoklu } \\
\text { karşılaştırma }\end{array}$ \\
\hline \multirow{3}{*}{ Psikolojik Wellness } & $21-23$ & 221 & 3,76 & 0,71 & & & \\
\hline & $24-26$ & 204 & 3,81 & 0,71 & 418 & 658 & \\
\hline & 27 ve üzeri & 91 & 3,81 & 0,65 & & & \\
\hline \multirow{3}{*}{ Duygusal Wellness } & $21-23$ & 221 & 4,04 & 0,92 & & & \\
\hline & $24-26$ & 204 & 4,06 & 0,87 & ,348 & ,706 & \\
\hline & 27 ve üzeri & 91 & 4,13 & 0,73 & & & \\
\hline \multirow{3}{*}{ Sosyal Wellness } & $21-23$ & 221 & 4,32 & 0,82 & & & \\
\hline & $24-26$ & 204 & 4,50 & 0,84 & 2,387 & ,093 & \\
\hline & 27 ve üzeri & 91 & 4,40 & 0,77 & & & \\
\hline \multirow{3}{*}{ Fiziksel Wellness } & $21-23$ & 221 & 3,67 & 0,73 & & & $1<3$ \\
\hline & $24-26$ & 204 & 3,83 & 0,90 & 3,064 &, $048^{*}$ & \\
\hline & 27 ve üzeri & 91 & 3,90 & 0,93 & & & \\
\hline \multirow{3}{*}{ Manevi Wellness } & $21-23$ & 221 & 4,01 & 0,91 & & & \\
\hline & $24-26$ & 204 & 3,99 & 0,97 & 2,241 & 107 & \\
\hline & 27 ve üzeri & 91 & 4,22 & 0,81 & & & \\
\hline \multirow{3}{*}{ Entelektüel Wellness } & $21-23$ & 221 & 3,85 & 0,67 & & & $1<3$ \\
\hline & $24-26$ & 204 & 3,89 & 0,71 & 4,342 &, $013^{*}$ & $2<3$ \\
\hline & 27 ve üzeri & 91 & 4,10 & 0,67 & & & \\
\hline \multirow{3}{*}{ Açık Alan Aktiviteleri } & $21-23$ & 221 & 2,28 & 0,56 & & & \\
\hline & $24-26$ & 204 & 2,24 & 0,62 & 634 &, 531 & \\
\hline & 27 ve üzeri & 91 & 2,21 & 0,50 & & & \\
\hline \multirow{3}{*}{ Spor Aktiviteleri } & $21-23$ & 221 & 1,78 & 0,52 & & & $2>3$ \\
\hline & $24-26$ & 204 & 1,88 & 0,65 & 3,277 &, $039^{*}$ & \\
\hline & 27 ve üzeri & 91 & 1,70 & 0,45 & & & \\
\hline \multirow{3}{*}{$\begin{array}{l}\text { Hobiler ve Açık Alan } \\
\text { Aktiviteleri }\end{array}$} & $21-23$ & 221 & 2,26 & 0,61 & & & \\
\hline & $24-26$ & 204 & 2,27 & 0,66 & 788 & 455 & \\
\hline & 27 ve üzeri & 91 & 2,18 & 0,47 & & & \\
\hline \multirow{3}{*}{$\begin{array}{l}\text { Kültürel Eğlence } \\
\text { Aktiviteleri }\end{array}$} & $21-23$ & 221 & 2,37 & 0,74 & & & \\
\hline & $24-26$ & 204 & 2,42 & 0,75 &, 389 & 678 & \\
\hline & 27 ve üzeri & 91 & 2,36 & 0,70 & & & \\
\hline \multirow{3}{*}{$\begin{array}{l}\text { Ev Merkezli Sosyal } \\
\text { Aktiviteler }\end{array}$} & $21-23$ & 221 & 3,24 & 0,65 & & & \\
\hline & $24-26$ & 204 & 3,14 & 0,69 & 1,044 & 353 & \\
\hline & 27 ve üzeri & 91 & 3,18 & 0,71 & & & \\
\hline \multirow{3}{*}{ Sosyal Aktiviteler } & $21-23$ & 221 & 2,05 & 0,86 & & & \\
\hline & $24-26$ & 204 & 1,96 & 0,91 & ,595 & ,552 & \\
\hline & 27 ve üzeri & 91 & 1,99 & 0,86 & & & \\
\hline
\end{tabular}

${ }^{*} p<0,05$

Öğrencilerin yaş dağılımları, boş zaman aktivitelerine katılımlarını etkileyen bir diğer faktördür. Güler (2017), beden eğitimi ve spor yüksekokullarında öğrenim gören öğrencilerin boş zaman engellerinin boş zaman motivasyonlarına etkisinin araştırılması üzerine yaptı̆̆ı çalışmasinda, 21-24 yaş grubu bireylerin boş zaman değerlendirme alışkanlıklarının 17-20 ile 25 ve üstü yaş grupları olan bireylerden anlamlı düzeyde 
yüksek olduğu belirlenmiştir. Yaş değişkenine bağlı olarak, sosyal uyum ve iletişim beceri düzeylerinde arasında anlamlı farklılıklar oluştuğunu tespit etmiştir. Myers ve arkadaşlarının (2003), yüksek lisansa yeni başlayan öğrenciler ile doktora öğrencilerinin iyi oluşları üzerine yaptıkları çalışmasında, doktora öğrencilerinin iyi oluş halinin yüksek olduğu sonuçlar elde etmiştir.Memnun'un (2006), beden eğitimi öğretmenlerinin esenlik algıları üzerine yaptığı çalışmasında, yaş değişkeni arttıkça manevi wellness boyutu puanının da arttığını belirtmiştir. Vural'ın (2016), yetişkinlerde alçakgönüllülük, dindarlık ve psikolojik iyi oluş ilişkisi

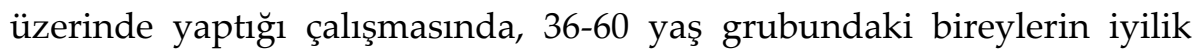
halinin 22-35 yaş grubundan yüksek olduğu sonucuna ulaşmıştır.

Tablo 6. Algılanan Wellness ve Boş Zaman Katılımın Yaşamın BüyükBölümünün Geçirildiği Yer Açısından İncelenmesi

\begin{tabular}{|c|c|c|c|c|c|c|c|}
\hline $\begin{array}{l}\text { Yaşamınızın büy } \\
\text { nerede geçirdiniz }\end{array}$ & bölümünü & $\mathbf{n}$ & Ortalama & ss & $\mathrm{f}$ & p & Çoklu karşılaştırma \\
\hline \multirow{4}{*}{$\begin{array}{l}\text { Psikolojik Well- } \\
\text { ness }\end{array}$} & köy-kasaba & 31 & 3,60 & 0,65 & \multirow{4}{*}{985} & \multirow{4}{*}{,399 } & \\
\hline & ilçe & 81 & 3,75 & 0,65 & & & \\
\hline & il & 191 & 3,80 & 0,67 & & & \\
\hline & büyükşehir & 213 & 3,82 & 0,74 & & & \\
\hline \multirow{4}{*}{$\begin{array}{l}\text { Duygusal Well- } \\
\text { ness }\end{array}$} & köy-kasaba & 31 & 3,67 & 0,92 & \multirow{4}{*}{4,923} & \multirow{4}{*}{, $002^{*}$} & $1<4$ \\
\hline & ilçe & 81 & 4,01 & 0,82 & & & $3<4$ \\
\hline & il & 191 & 3,99 & 0,90 & & & \\
\hline & büyükşehir & 213 & 4,21 & 0,82 & & & \\
\hline \multirow{4}{*}{ Sosyal Wellness } & köy-kasaba & 31 & 4,04 & 0,86 & \multirow{4}{*}{7,935} & \multirow{4}{*}{, $000^{*}$} & $1<2$ \\
\hline & ilçe & 81 & 4,51 & 0,72 & & & $1<4$ \\
\hline & il & 191 & 4,24 & 0,82 & & & $3<4$ \\
\hline & büyükşehir & 213 & 4,57 & 0,81 & & & \\
\hline \multirow{4}{*}{ Fiziksel Wellness } & köy-kasaba & 31 & 3,91 & 0,76 & \multirow{4}{*}{, 559} & \multirow{4}{*}{,642 } & \\
\hline & ilçe & 81 & 3,78 & 0,82 & & & \\
\hline & il & 191 & 3,72 & 0,79 & & & \\
\hline & büyükşehir & 213 & 3,80 & 0,91 & & & \\
\hline \multirow{4}{*}{ Manevi Wellnes } & köy-kasaba & 31 & 3,62 & 0,95 & \multirow[t]{4}{*}{3,947} & \multirow[t]{4}{*}{, $008^{*}$} & $1<4$ \\
\hline & ilçe & 81 & 4,02 & 0,78 & & & \\
\hline & il & 191 & 3,97 & 0,98 & & & \\
\hline & büyükşehir & 213 & 4,17 & 0,88 & & & \\
\hline \multirow{4}{*}{$\begin{array}{l}\text { Entelektüel } \\
\text { Wellness }\end{array}$} & köy-kasaba & 31 & 3,68 & 0,57 & \multirow{4}{*}{4,457} & \multirow{4}{*}{, $004^{*}$} & $3<4$ \\
\hline & ilçe & 81 & 4,03 & 0,67 & & & \\
\hline & il & 191 & 3,80 & 0,70 & & & \\
\hline & büyükşehir & 213 & 3,99 & 0,69 & & & \\
\hline \multirow{4}{*}{$\begin{array}{l}\text { Açık Alan } \\
\text { Aktiviteleri }\end{array}$} & köy-kasaba & 31 & 2,39 & 0,56 & \multirow{4}{*}{2,417} & \multirow{4}{*}{,066 } & \\
\hline & ilçe & 81 & 2,38 & 0,57 & & & \\
\hline & il & 191 & 2,23 & 0,66 & & & \\
\hline & büyükşehir & 213 & 2,21 & 0,49 & & & \\
\hline \multirow{4}{*}{ Spor Aktiviteleri } & köy-kasaba & 31 & 1,66 & 0,41 & \multirow{4}{*}{1,559} & \multirow{4}{*}{ 199 } & \\
\hline & ilçe & 81 & 1,74 & 0,56 & & & \\
\hline & il & 191 & 1,86 & 0,71 & & & \\
\hline & büyükşehir & 213 & 1,81 & 0,44 & & & \\
\hline
\end{tabular}




\begin{tabular}{|c|c|c|c|c|c|c|c|}
\hline \multirow{4}{*}{$\begin{array}{l}\text { Hobiler ve Açık } \\
\text { Alan Aktiviteleri }\end{array}$} & köy-kasaba & 31 & 2,10 & 0,39 & \multirow{4}{*}{,978 } & \multirow{4}{*}{,403 } & \\
\hline & ilçe & 81 & 2,20 & 0,53 & & & \\
\hline & il & 191 & 2,28 & 0,74 & & & \\
\hline & büyükşehir & 213 & 2,26 & 0,53 & & & \\
\hline \multirow{4}{*}{$\begin{array}{l}\text { Kültürel Eğlence } \\
\text { Aktiviteleri }\end{array}$} & köy-kasaba & 31 & 2,19 & 0,76 & \multirow{4}{*}{4,276} & \multirow{4}{*}{, $005^{*}$} & $2<4$ \\
\hline & ilçe & 81 & 2,20 & 0,64 & & & \\
\hline & il & 191 & 2,38 & 0,79 & & & \\
\hline & büyükşehir & 213 & 2,50 & 0,69 & & & \\
\hline \multirow{4}{*}{$\begin{array}{l}\text { Ev Merkezli } \\
\text { Sosyal Aktiviteler }\end{array}$} & köy-kasaba & 31 & 3,17 & 0,50 & \multirow{4}{*}{600} & \multirow{4}{*}{,615 } & \\
\hline & ilçe & 81 & 3,10 & 0,71 & & & \\
\hline & il & 191 & 3,20 & 0,70 & & & \\
\hline & büyükşehir & 213 & 3,22 & 0,67 & & & \\
\hline \multirow{4}{*}{ Sosyal Aktiviteler } & köy-kasaba & 31 & 1,96 & 0,64 & \multirow{4}{*}{1,136} & \multirow{4}{*}{,334 } & \\
\hline & ilçe & 81 & 2,14 & 0,92 & & & \\
\hline & il & 191 & 2,03 & 0,93 & & & \\
\hline & büyükşehir & 213 & 1,94 & 0,85 & & & \\
\hline
\end{tabular}

${ }^{*} p<0,05$

Öğrencilerin yaşamlarının büyük bölümünü geçirdikleri yer açısından boş zaman katılım düzeyleri incelendiğinde, kültürel eğlence aktivitelerine katılımlarında anlamlı bir farklılığın olduğu saptanmıştır $(p<0,05)$ ve buna göre büyükşehirde geçirmiş olanların puan ortalaması en büyük iken köy-kasabada geçirmiş olanların ortalaması en küçük olduğu tespit edilmiştir. Öğrencilerin yaşamlarının büyük bölümünü geçirdikleri yer açısından algılanan wellness düzeyleri incelendiğinde, duygusal, sosyal, manevi ve entelektüel wellness alt boyutlarında anlam11 farklılık bulunmaktadır $(p<0,05)$. Ortalama puanlar incelendiğinde yaşamlarının büyük bölümünü büyükşehirde geçirmiş olanların duygusal, sosyal, manevi ve entelektüel wellness düzeylerinin en büyük, köykasabada geçirmiş olanların ortalaması ise en küçük olduğu tespit edilmiştir.

Öğrencilerin yaşadıkları yer bakımından, boş zaman aktivitelerine katılımları da değişkenlik göstermektedir. Arslan'ın (2014), üniversite öğrencilerinin boş zaman değerlendirme tercihleri üzerine yaptığ 1 çalışmasinda, kentsel bölgede yaşayan öğrencilerin aşina oldukları rekreasyon alanlarından daha fazla yararlandıklarını; Önal'ın (2017), Atatürk Üniversitesi öğrencilerinin boş zaman tutumları ile boş zaman aktivitelerine katılımını engelleyen faktörlerin incelenmesi üzerine yaptığı çalışmasında, bireylerin yaşadıkları yerleşim birimine göre ilçe ve köylerde yaşayan bireylerin şehir merkezinde yaşayan bireylere göre bilgi eksikliğinden daha fazla etkilendiklerini, yapılacak olan rekreasyon aktivitelerini nerden öğreneceğini bilmemek veya öğretecek kimsenin olmaması, şehir 
merkezinde yaşayanlarda fazla engel oluşturmadığı, dolayısıyla köy ve ilçelerde yaşayan bireylerin aktivitelere katılımda şehir merkezinde yaşayan bireylere göre bihaber olduklarını ifade etmiştir.

Tablo 7. Algılanan Wellness ve Boş Zaman Katılımın Öğrenim Durumu Açısından İncelenmesi

\begin{tabular}{|c|c|c|c|c|c|c|}
\hline Öğrenim durumunuz? & & $\mathbf{n}$ & Ortalama & ss & $t$ & $\mathrm{p}$ \\
\hline \multirow{2}{*}{ Psikolojik Wellness } & son sinif & 162 & 3,82 & 0,70 & \multirow{2}{*}{,747 } & \multirow{2}{*}{,455 } \\
\hline & mezun & 354 & 3,77 & 0,70 & & \\
\hline \multirow{2}{*}{ Duygusal Wellness } & son sinif & 162 & 3,91 & 0,95 & \multirow{2}{*}{$-2,794$} & \multirow{2}{*}{, $005^{*}$} \\
\hline & mezun & 354 & 4,14 & 0,82 & & \\
\hline \multirow[b]{2}{*}{ Sosyal Wellness } & son sinif & 162 & 4,15 & 0,80 & \multirow[b]{2}{*}{$-4,972$} & \multirow[b]{2}{*}{, $000^{*}$} \\
\hline & mezun & 354 & 4,53 & 0,80 & & \\
\hline \multirow{2}{*}{ Fiziksel Wellness } & son sinif & 162 & 3,70 & 0,85 & \multirow{2}{*}{$-1,417$} & \multirow{2}{*}{,157 } \\
\hline & mezun & 354 & 3,81 & 0,84 & & \\
\hline \multirow{2}{*}{ Manevi Wellness } & son sinif & 162 & 4,01 & 0,97 & \multirow{2}{*}{,- 419} & \multirow[b]{2}{*}{676} \\
\hline & mezun & 354 & 4,05 & 0,89 & & \\
\hline \multirow{2}{*}{ Entelektüel Wellness } & son sinif & 162 & 3,82 & 0,69 & \multirow{2}{*}{$-2,016$} & \multirow{2}{*}{, $044^{*}$} \\
\hline & mezun & 354 & 3,95 & 0,69 & & \\
\hline \multirow{2}{*}{ Açık Alan Aktiviteleri } & son sinif & 162 & 2,28 & 0,62 & \multirow{2}{*}{672} & \multirow{2}{*}{, 502} \\
\hline & mezun & 354 & 2,24 & 0,55 & & \\
\hline \multirow{2}{*}{ Spor Aktiviteleri } & son sinif & 162 & 1,88 & 0,67 & \multirow{2}{*}{1,914} & \multirow{2}{*}{056} \\
\hline & mezun & 354 & 1,77 & 0,51 & & \\
\hline \multirow{2}{*}{$\begin{array}{l}\text { Hobiler ve Açık Alan } \\
\text { Aktiviteleri }\end{array}$} & son sinif & 162 & 2,27 & 0,72 & \multirow{2}{*}{, 541} & \multirow{2}{*}{, 588} \\
\hline & mezun & 354 & 2,24 & 0,55 & & \\
\hline \multirow{2}{*}{ Kültürel Eğlence Aktiviteleri } & son sinif & 162 & 2,32 & 0,78 & \multirow{2}{*}{$-1,409$} & \multirow{2}{*}{, 160 } \\
\hline & mezun & 354 & 2,42 & 0,71 & & \\
\hline \multirow{2}{*}{$\begin{array}{l}\text { Ev Merkezli Sosyal } \\
\text { Aktiviteler }\end{array}$} & son sinif & 162 & 3,26 & 0,66 & \multirow{2}{*}{1,562} & \multirow{2}{*}{,119 } \\
\hline & mezun & 354 & 3,16 & 0,68 & & \\
\hline Sosval Aktiviteler & son sinif & 162 & 2,13 & 0,96 & 2238 & $026 *$ \\
\hline Sosyal Aktıviteler & mezun & 354 & 1,95 & 0,84 & 2,238 &, $026^{*}$ \\
\hline
\end{tabular}

${ }^{*} p<0,05$

Öğrencilerin öğrenim durumlarına göre boş zaman katılım düzeyleri incelendiğinde, sosyal aktivitelere katılımlarında anlamlı bir farklılığın olduğu saptanmıştır $(p<0,05)$ ve ortalama puanlar incelendiğinde son sinıf öğrencilerinin sosyal aktivitelere katılım düzeyleri daha büyük olduğu tespit edilmiştir. Öğrencilerin öğrenim durumlarına göre algılanan wellness düzeyleri incelendiğinde, duygusal, sosyal ve entelektüel wellness alt boyutlarında anlamlı farklılık bulunmaktadır $(\mathrm{p}<0,05)$. Ortalama puanlar incelendiğinde mezun olanların duygusal, sosyal ve entelektüel wellness düzeyleri daha büyük olduğu tespit edilmiştir.

Öğrencilerin öğrenim durumları, boş zaman aktivitelerine katılımlarını etkileyen faktörler arasındadır. Alanyazında mevcut çalışmalar eği- 
tim düzeyi arttıkça bireylerin iyilik düzeylerinin arttığ 1 yönündedir. Cummins'in (2000), kişisel gelir ve öznel refah üzerine yaptığı çalışmasında da eğitimle birlikte bireylerin iyi oluşlarının arttığını, eğitim ile iyi oluş arasında pozitif yönlü zayıf bir ilişki olduğunu öne sürmüştür. Bu durumun eğitimle birlikte bireylerin gelir düzeylerindeki artışa ve bireylerin refah düzeyinin, alım gücünün artması ile birlikte sağlık, beslenme, fiziksel aktivite gibi birçok faktörü etkileyerek iyi oluşa olumlu katkıda bulunmasına bağlamaktadır.Enochs (2001), üniversite öğrencileri ile yaptığı çalışmada 4.sınıf öğrencilerinin toplam iyilik hali puanlarının 1. sınıflardan yüksek olduğunu bulmuştur. Tsai'nin (2004) 55-75 yaş aralığındaki yetişkinlerde boş zamana katılım ve algılanan sağlık arasındaki ilişki üzerine yaptığı çalışmasında, daha yüksek eğitim seviyesine sahip yaşlıların algılanan sağlık seviyesinin daha yüksek olduğunu, daha fazla bilgiye ve farklı yaşam tarzlarını keşfetme becerisine sahip olduklarını, fiziksel aktiviteler, sanat ve diğer kültürel uğraşılarda daha aktif ve bilgiye erişme olasılıkları daha yüksek, sağlıkları hakkında ve günlük baskılardan uzaklaşmak ve enerjik bir yaşam sürdürmek için sıklıkla boş zaman aktivitelerini kullanan bireyler olduğunu ifade etmiştir. Eruzun'un (2017), kadınların spor etkinliklerine katılımlarının boş zaman tatmini ve yaşam kalitesine etkilerinin incelendiği çalışmasında, eğitim düzeyi ön lisans/lisan olanlar ile lisansüstü olanlar arasında anlamlı bir farklılık bulunmazken, eğitim düzeyi ön lisans/lisans olanlar ile lise olanlar arasında anlamlı bulunmaktadır. Buna göre kadınların eğitim düzeyi arttıkça yaşam kalitesi düzeylerinin arttığı, psikolojik kalite düzeylerinde ve sosyal kalite düzeylerinde artış gözlemlenmiştir.

Öğrencilerin aylık toplam bütçe açısından boş zaman katılım düzeyleri incelendiğinde, spor aktivitelere katılımlarında anlamlı bir farklılığın olduğu saptanmıştır $(\mathrm{p}<0,05)$. Buna göre bütçesi $751 \mathrm{TL}$ - $1250 \mathrm{TL}$ olanların puan ortalaması en büyük iken, $250 \mathrm{TL}$ - 750 TL olanların ortalaması en küçük olduğu tespit edilmiştir. Öğrencilerin aylık toplam bütçe aç1sindan algılanan wellness düzeyleri incelendiğinde, psikolojik wellness alt boyutunda anlamlı farklılık bulunmaktadır $(\mathrm{p}<0,05)$. Buna göre bütçesi $751 \mathrm{TL}$ - $1250 \mathrm{TL}$ olanların puan ortalaması en büyük iken, $250 \mathrm{TL}$ 750 TL olanların ortalaması en küçük olduğu tespit edilmiştir. 
Tablo 8. Algılanan Wellness ve Boş Zaman Katılımın Aylık Toplam Bütçe Açısından Incelenmesi

\begin{tabular}{|c|c|c|c|c|c|c|c|}
\hline \multicolumn{2}{|c|}{ Aylık toplam bütçeniz? } & \multirow{2}{*}{$\begin{array}{l}\mathbf{n} \\
282\end{array}$} & \multirow{2}{*}{$\begin{array}{c}\text { Ortalama } \\
3,74\end{array}$} & \multirow{2}{*}{$\begin{array}{r}\text { ss } \\
0,68\end{array}$} & \multirow[t]{2}{*}{$\mathrm{F}$} & \multirow[t]{2}{*}{$\mathrm{p}$} & \multirow{2}{*}{$\begin{array}{c}\text { Çoklu karşılaştırma } \\
1<2\end{array}$} \\
\hline \multirow{4}{*}{$\begin{array}{l}\text { Psikolojik } \\
\text { Wellness }\end{array}$} & $250 \mathrm{TL}-750 \mathrm{TL}$ & & & & & & \\
\hline & $751 \mathrm{TL}-1250 \mathrm{TL}$ & 90 & 3,97 & 0,67 & \multirow{3}{*}{2,684} & \multirow{3}{*}{, $046^{*}$} & \\
\hline & $1251 \mathrm{TL}-1750 \mathrm{TL}$ & 40 & 3,82 & 0,90 & & & \\
\hline & 1751 TL ve üzeri & 104 & 3,76 & 0,67 & & & \\
\hline \multirow{4}{*}{$\begin{array}{l}\text { Duygusal } \\
\text { Wellness }\end{array}$} & $250 \mathrm{TL}-750 \mathrm{TL}$ & 282 & 4,01 & 0,89 & \multirow{4}{*}{1,959} & \multirow{4}{*}{,119 } & \\
\hline & $751 \mathrm{TL}-1250 \mathrm{TL}$ & 90 & 4,05 & 0,92 & & & \\
\hline & $1251 \mathrm{TL}-1750 \mathrm{TL}$ & 40 & 4,00 & 0,98 & & & \\
\hline & 1751 TL ve üzeri & 104 & 4,25 & 0,70 & & & \\
\hline \multirow{4}{*}{$\begin{array}{l}\text { Sosyal Well- } \\
\text { ness }\end{array}$} & $250 \mathrm{TL}-750 \mathrm{TL}$ & 282 & 4,37 & 0,82 & \multirow{4}{*}{1,133} & \multirow{4}{*}{,335 } & \\
\hline & $751 \mathrm{TL}$ - $1250 \mathrm{TL}$ & 90 & 4,54 & 0,80 & & & \\
\hline & $1251 \mathrm{TL}-1750 \mathrm{TL}$ & 40 & 4,33 & 0,86 & & & \\
\hline & 1751 TL ve üzeri & 104 & 4,44 & 0,85 & & & \\
\hline \multirow{4}{*}{$\begin{array}{l}\text { Fiziksel } \\
\text { Wellness }\end{array}$} & $250 \mathrm{TL}-750 \mathrm{TL}$ & 282 & 3,72 & 0,79 & \multirow{4}{*}{0,892} & \multirow{4}{*}{,445 } & \\
\hline & $751 \mathrm{TL}$ - $1250 \mathrm{TL}$ & 90 & 3,79 & 0,92 & & & \\
\hline & $1251 \mathrm{TL}-1750 \mathrm{TL}$ & 40 & 3,83 & 0,72 & & & \\
\hline & 1751 TL ve üzeri & 104 & 3,88 & 0,95 & & & \\
\hline \multirow{4}{*}{$\begin{array}{l}\text { Manevi } \\
\text { Wellness }\end{array}$} & $250 \mathrm{TL}-750 \mathrm{TL}$ & 282 & 3,97 & 0,89 & \multirow{4}{*}{1,415} & & \\
\hline & $751 \mathrm{TL}-1250 \mathrm{TL}$ & 90 & 4,13 & 0,97 & & 237 & \\
\hline & $1251 \mathrm{TL}-1750 \mathrm{TL}$ & 40 & 4,00 & 1,10 & & 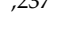 & \\
\hline & 1751 TL ve üzeri & 104 & 4,16 & 0,84 & & & \\
\hline & $250 \mathrm{TL}-750 \mathrm{TL}$ & 282 & 3,90 & 0,67 & & & \\
\hline Entelektüel & $751 \mathrm{TL}$ - $1250 \mathrm{TL}$ & 90 & 3,89 & 0,69 & & & \\
\hline Wellness & $1251 \mathrm{TL}-1750 \mathrm{TL}$ & 40 & 3,83 & 0,88 & 0,477 & 699 & \\
\hline & 1751 TL ve üzeri & 104 & 3,97 & 0,69 & & & \\
\hline & $250 \mathrm{TL}-750 \mathrm{TL}$ & 282 & 2,25 & 0,56 & & & \\
\hline Açık Alan & $751 \mathrm{TL}-1250 \mathrm{TL}$ & 90 & 2,16 & 0,55 & 1807 & 145 & \\
\hline Aktiviteleri & $1251 \mathrm{TL}-1750 \mathrm{TL}$ & 40 & 2,40 & 0,54 & 1,807 & , & \\
\hline & 1751 TL ve üzeri & 104 & 2,30 & 0,63 & & & \\
\hline & $250 \mathrm{TL}-750 \mathrm{TL}$ & 282 & 1,75 & 0,56 & & & $1<2$ \\
\hline Spor & $751 \mathrm{TL}$ - $1250 \mathrm{TL}$ & 90 & 1,94 & 0,68 & & & \\
\hline Aktiviteleri & $1251 \mathrm{TL}-1750 \mathrm{TL}$ & 40 & 1,79 & 0,60 & 2,685 &, $046^{*}$ & \\
\hline & 1751 TL ve üzeri & 104 & 1,83 & 0,47 & & & \\
\hline & $250 \mathrm{TL}-750 \mathrm{TL}$ & 282 & 2,20 & 0,60 & & & \\
\hline Hobiler ve & $751 \mathrm{TL}$ - $1250 \mathrm{TL}$ & 90 & 2,35 & 0,74 & 404 & 050 & \\
\hline $\begin{array}{l}\text { AçIK Alan } \\
\text { Aktiviteleri }\end{array}$ & $1251 \mathrm{TL}-1750 \mathrm{TL}$ & 40 & 2,41 & 0,58 & 2,494 & , & \\
\hline & 1751 TL ve üzeri & 104 & 2,22 & 0,50 & & & \\
\hline & $250 \mathrm{TL}-750 \mathrm{TL}$ & 282 & 2,39 & 0,78 & & & \\
\hline Kültürel & $751 \mathrm{TL}$ - $1250 \mathrm{TL}$ & 90 & 2,44 & 0,62 & & & \\
\hline Eğlence & $1251 \mathrm{TL}-1750 \mathrm{TL}$ & 40 & 2,39 & 0,79 & 0,301 & 825 & \\
\hline & 1751 TL ve üzeri & 104 & 2,34 & 0,70 & & & \\
\hline & $250 \mathrm{TL}-750 \mathrm{TL}$ & 282 & 3,16 & 0,64 & & & \\
\hline Ev Merkezli & $751 \mathrm{TL}$ - $1250 \mathrm{TL}$ & 90 & 3,17 & 0,69 & 1290 & & \\
\hline $\begin{array}{l}\text { Sosyal } \\
\text { Aktiviteler }\end{array}$ & $1251 \mathrm{TL}-1750 \mathrm{TL}$ & 40 & 3,38 & 0,80 & 1,290 & ,277 & \\
\hline & 1751 TL ve üzeri & 104 & 3,22 & 0,71 & & & \\
\hline & $250 \mathrm{TL}-750 \mathrm{TL}$ & 282 & 1,99 & 0,86 & & & \\
\hline Sosyal & $751 \mathrm{TL}$ - $1250 \mathrm{TL}$ & 90 & 2,04 & 0,88 & 0512 & 671 & \\
\hline Aktiviteleri & $1251 \mathrm{TL}-1750 \mathrm{TL}$ & 40 & 2,15 & 0,87 & 0,012 & ,6/4 & \\
\hline & 1751 TL ve üzeri & 104 & 1,96 & 0,95 & & & \\
\hline
\end{tabular}

${ }^{*} p<0,05$ 
Öğrencilerin gelir düzeyleri, boş zaman aktivitelerine katılım düzeylerini etkileyen önemli bir faktördür. Öğrencilerin geliri arttıç̧a boş zaman aktivitelerini keşfetmeleri ve katılımları için fırsatları artmaktadır. Süzer (2000) çalışmasında öğrencilerin boş zaman faaliyetlerine katılmalarında ellerine geçen para miktarının önemli etkisi olduğunu ve öğrencilerin ellerine geçen aylık para miktarı arttıkça, boş zaman faaliyetleri için harcadıkları para miktarının da arttığını; Terzioğlu ve Yazıcı'nın (2003) çalışmalarında, öğrencilerin gelir düzeyleri ile boş zamanları arasinda bir doğru orantı olduğunu; Ardahan ve Yerlisu Lapa'nın (2010), üniversite öğrencilerinin serbest zaman tatmin düzeylerinin cinsiyete ve gelire göre incelenmesi üzerine yaptıkları çalışmalarında öğrencilerin gelir düzeyleri arttıkça boş zaman tatmin düzeylerinin de arttığını tespit etmişlerdir. Gelir durumu orta ya da yüksek olan bireylerin boş zaman aktivitelerine katılımlarında ve dolayısıyla yaşam kalitelerinde de pozitif yönde bir artış olacağı düşünülmektedir.

Tablo 9. Algılanan Wellness ve Boş Zaman Katılımın Günlük Yapmak Zorunda Olunan İşler Dışında Kendine Ayrılan Süre Açısından İncelenmesi

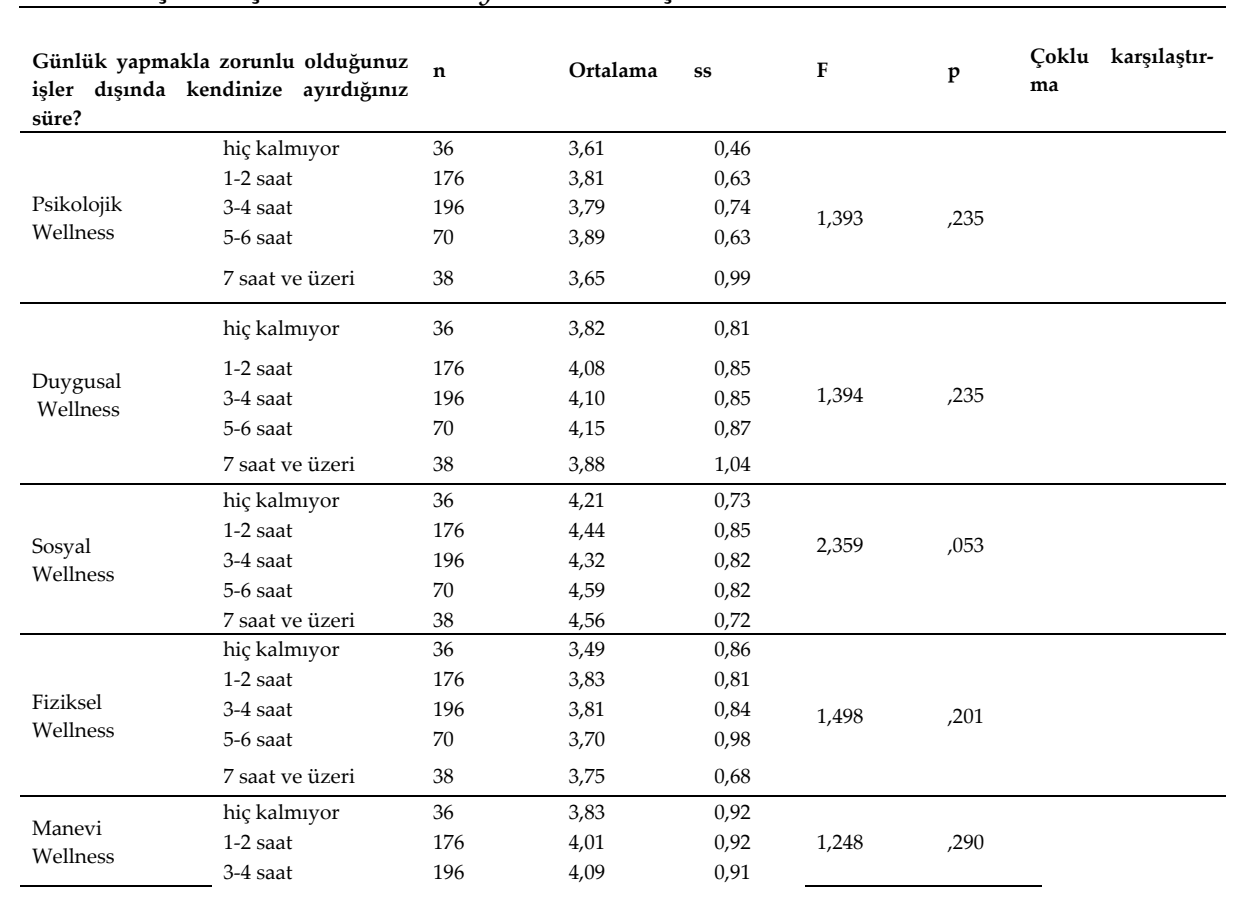




\begin{tabular}{|c|c|c|c|c|c|c|c|}
\hline & 5-6 saat & 70 & 4,16 & 0,81 & & & \\
\hline & 7 saat ve üzeri & 38 & 3,89 & 1,10 & & & \\
\hline \multirow{5}{*}{$\begin{array}{l}\text { Entelektüel } \\
\text { Wellness }\end{array}$} & hiç kalmıyor & 36 & 3,76 & 0,58 & \multirow{5}{*}{0,982} & \multirow{5}{*}{417} & \\
\hline & 1-2 saat & 176 & 3,93 & 0,64 & & & \\
\hline & 3-4 saat & 196 & 3,95 & 0,73 & & & \\
\hline & 5-6 saat & 70 & 3,90 & 0,78 & & & \\
\hline & 7 saat ve üzeri & 38 & 3,78 & 0,67 & & & \\
\hline \multirow{5}{*}{$\begin{array}{l}\text { Açık Alan } \\
\text { Aktiviteleri }\end{array}$} & hiç kalmiyor & 36 & 2,01 & 0,46 & \multirow{5}{*}{2,808} & \multirow{5}{*}{, $025^{*}$} & $1<3$ \\
\hline & 1-2 saat & 176 & 2,24 & 0,58 & & & \\
\hline & 3-4 saat & 196 & 2,33 & 0,57 & & & \\
\hline & 5-6 saat & 70 & 2,18 & 0,58 & & & \\
\hline & 7 saat ve üzeri & 38 & 2,30 & 0,59 & & & \\
\hline \multirow{5}{*}{$\begin{array}{l}\text { Spor } \\
\text { Aktiviteleri }\end{array}$} & hiç kalmıyor & 36 & 1,48 & 0,38 & \multirow{5}{*}{4,323} & \multirow{5}{*}{, $002^{*}$} & $1<2$ \\
\hline & 1-2 saat & 176 & 1,81 & 0,54 & & & $1<3$ \\
\hline & 3-4 saat & 196 & 1,85 & 0,61 & & & $1<5$ \\
\hline & 5-6 saat & 70 & 1,76 & 0,48 & & & \\
\hline & 7 saat ve üzeri & 38 & 1,97 & 0,68 & & & \\
\hline \multirow{5}{*}{$\begin{array}{l}\text { Hobiler ve } \\
\text { Açık Alan } \\
\text { Aktiviteleri }\end{array}$} & hiç kalmıyor & 36 & 1,89 & 0,53 & \multirow{5}{*}{3,788} & \multirow{5}{*}{, $005^{*}$} & $1<2$ \\
\hline & 1-2 saat & 176 & 2,29 & 0,64 & & & $1<3$ \\
\hline & 3-4 saat & 196 & 2,28 & 0,58 & & & $1<5$ \\
\hline & 5-6 saat & 70 & 2,19 & 0,53 & & & \\
\hline & 7 saat ve üzeri & 38 & 2,32 & 0,71 & & & \\
\hline \multirow{5}{*}{$\begin{array}{l}\text { Kültürel } \\
\text { Eğlence } \\
\text { Aktiviteleri }\end{array}$} & hiç kalmiyor & 36 & 1,98 & 0,65 & \multirow{5}{*}{3,327} & \multirow{5}{*}{, $010^{*}$} & $1<2$ \\
\hline & 1-2 saat & 176 & 2,42 & 0,74 & & & $1<3$ \\
\hline & 3-4 saat & 196 & 2,46 & 0,71 & & & \\
\hline & 5-6 saat & 70 & 2,35 & 0,76 & & & \\
\hline & 7 saat ve üzeri & 38 & 2,38 & 0,79 & & & \\
\hline \multirow{5}{*}{$\begin{array}{l}\text { Ev Merkezli } \\
\text { Sosyal } \\
\text { Aktiviteler }\end{array}$} & hiç kalmıyor & 36 & 2,98 & 0,56 & \multirow{5}{*}{2,022} & \multirow{5}{*}{,090 } & \\
\hline & 1-2 saat & 176 & 3,20 & 0,59 & & & \\
\hline & 3-4 saat & 196 & 3,19 & 0,64 & & & \\
\hline & 5-6 saat & 70 & 3,16 & 0,83 & & & \\
\hline & 7 saat ve üzeri & 38 & 3,42 & 0,94 & & & \\
\hline \multirow{5}{*}{$\begin{array}{l}\text { Sosyal } \\
\text { Aktiviteler }\end{array}$} & hiç kalmiyor & 36 & 1,81 & 0,60 & \multirow{5}{*}{1,396} & \multirow{5}{*}{,234 } & \\
\hline & 1-2 saat & 176 & 2,00 & 0,90 & & & \\
\hline & 3-4 saat & 196 & 2,04 & 0,89 & & & \\
\hline & 5-6 saat & 70 & 1,89 & 0,83 & & & \\
\hline & 7 saat ve üzeri & 38 & 2,22 & 1,04 & & & \\
\hline
\end{tabular}

${ }^{*} p<0,05$

Öğrencilerin günlük yapmak zorunda oldukları işler dışında kendine ayırdıkları süre açısından boş zaman katılım düzeyleri incelendiğinde, açlk alan aktivitelerine, spor aktivitelerine, hobiler ve açık alan aktivitelerine, kültürel eğlence aktivitelerine katılımlarında anlamlı bir farklılığın olduğu saptanmıştır $(p<0,05)$. Ortalama puanlar incelendiğinde günlük 3-4 saat ayıranların açık alan aktivitelerine, kültürel eğlence aktivitelerine katılım düzeylerinin en büyük iken hiç vakti kalmayanların ortalaması en küçük, 7 saat ve üzeri ayıranların, spor aktivitelerine, hobiler ve açık alan aktivitelerine katılım düzeylerinin daha büyükken hiç vakti kalmayanların ortalaması en küçük olduğu tespit edilmiştir. Öğrencilerin günlük yapmak zorunda oldukları işler dışında kendine ayırdıkları 
süre açısından algılanan wellness düzeyleri incelendiğinde, anlamlı bir farklılık bulunmamaktadır.

Yerlisu Lapa ve Ağyar (2012) çalışmasında, üniversite öğrencilerinin spor ve sosyal etkinliklere doğrudan katıldıkları, sanat ve kültür faaliyetlerine de genelde pasif olarak katılım sağladıklarını tespit etmişler ve öğrencilerin boş zaman etkinliklerine ayda 29 ortalama 3-4 kez katıldıkları görülmüştür. Ayrıca etkinliklere katılım oranlarındaki artışla birlikte algılanan özgürlük düzeyleride artış gösterdiğini; Tercan Kaas (2015) çalışmasında, öğrenciler boş zaman etkinliklerine genelde arkadaşlarıyla katıldıklarını, rekreasyon faaliyetlerine haftada en fazla 10 saate kadar katılım gösterdiklerini ve haftada en fazla 3-4 kez boş zaman etkinliklerine katıldıklarını; Çoruh ve Karaküçük (2014), üniversite öğrencilerin haftada ortalama 3 ile 6 saat boş zaman imkanlarının oldukları görülürken öğrencilerin rekreasyon faaliyeti olarak fiziksel aktiviteye yeterli düzeyde katılmadığını tespit etmişlerdir.

Tablo 10. Algılanan Wellness ve Boş Zaman Katılımın Haftalık Sahip Olunan Boş Zaman Süresi Açısından İncelenmesi

\begin{tabular}{|c|c|c|c|c|c|c|c|}
\hline \multicolumn{2}{|c|}{$\begin{array}{l}\text { Haftalık sahip olduğunuz boş } \\
\text { zaman süresinin size göre } \\
\text { yeterliliği? }\end{array}$} & \multirow{2}{*}{$\begin{array}{l}\mathbf{n} \\
222\end{array}$} & \multirow{2}{*}{$\begin{array}{c}\text { Ortalama } \\
3,74\end{array}$} & ss & \multirow[t]{2}{*}{$\mathbf{F}$} & \multirow[t]{2}{*}{$\mathrm{p}$} & \multirow[t]{2}{*}{$\begin{array}{l}\text { Çoklu } \\
\text { karşılaştırma }\end{array}$} \\
\hline \multirow{3}{*}{$\begin{array}{l}\text { Psikolojik } \\
\text { Wellnes }\end{array}$} & yetersiz & & & 0,71 & & & \\
\hline & normal & 154 & 3,81 & 0,65 & \multirow[t]{2}{*}{1,014} & \multirow[t]{2}{*}{,363 } & \\
\hline & yeterli & 140 & 3,84 & 0,73 & & & \\
\hline \multirow{3}{*}{$\begin{array}{l}\text { Duygusal } \\
\text { Wellnes }\end{array}$} & yetersiz & 222 & 4,04 & 0,88 & \multirow{3}{*}{0,127} & \multirow{3}{*}{881} & \\
\hline & normal & 154 & 4,09 & 0,89 & & & \\
\hline & yeterli & 140 & 4,08 & 0,84 & & & \\
\hline \multirow{3}{*}{$\begin{array}{l}\text { Sosyal } \\
\text { Wellnes }\end{array}$} & yetersiz & 222 & 4,42 & 0,78 & \multirow{3}{*}{1,759} & \multirow{3}{*}{,173 } & \\
\hline & normal & 154 & 4,31 & 0,84 & & & \\
\hline & yeterli & 140 & 4,49 & 0,86 & & & \\
\hline \multirow{3}{*}{$\begin{array}{l}\text { Fiziksel } \\
\text { Wellnes }\end{array}$} & yetersiz & 222 & 3,73 & 0,90 & \multirow{3}{*}{1,061} & \multirow{3}{*}{, 347} & \\
\hline & normal & 154 & 3,86 & 0,82 & & & \\
\hline & yeterli & 140 & 3,75 & 0,76 & & & \\
\hline \multirow{3}{*}{$\begin{array}{l}\text { Manevi } \\
\text { Wellnes }\end{array}$} & yetersiz & 222 & 3,93 & 0,97 & \multirow{3}{*}{4,153} & \multirow{3}{*}{, $016^{*}$} & $1<3$ \\
\hline & normal & 154 & 4,05 & 0,83 & & & \\
\hline & yeterli & 140 & 4,21 & 0,90 & & & \\
\hline \multirow{3}{*}{$\begin{array}{l}\text { Entelektüel } \\
\text { Wellnes }\end{array}$} & yetersiz & 222 & 3,79 & 0,64 & \multirow{3}{*}{5,794} & \multirow{3}{*}{,003 } & $1<2$ \\
\hline & normal & 154 & 4,01 & 0,70 & & & $1<3$ \\
\hline & yeterli & 140 & 3,98 & 0,74 & & & \\
\hline \multirow{3}{*}{$\begin{array}{l}\text { Açık Alan } \\
\text { Aktiviteleri }\end{array}$} & yetersiz & 222 & 2,12 & 0,49 & \multirow{3}{*}{11,184} & \multirow{3}{*}{, $000^{*}$} & $1<2$ \\
\hline & normal & 154 & 2,34 & 0,60 & & & $1<3$ \\
\hline & yeterli & 140 & 2,37 & 0,62 & & & \\
\hline \multirow[b]{2}{*}{ Spor Aktiviteleri } & yetersiz & 222 & 1,67 & 0,44 & \multirow[b]{2}{*}{12,277} & \multirow[b]{2}{*}{, $000^{*}$} & $1<2$ \\
\hline & normal & 154 & 1,89 & 0,59 & & & $1<3$ \\
\hline
\end{tabular}




\begin{tabular}{|c|c|c|c|c|c|c|c|}
\hline & yeterli & 140 & 1,94 & 0,66 & & & \\
\hline \multirow{3}{*}{$\begin{array}{l}\text { Hobiler ve Açık } \\
\text { Alan Aktiviteleri }\end{array}$} & yetersiz & 222 & 2,14 & 0,52 & \multirow{3}{*}{6,250} & \multirow{3}{*}{, $002^{*}$} & $1<2$ \\
\hline & normal & 154 & 2,30 & 0,58 & & & $1<3$ \\
\hline & yeterli & 140 & 2,36 & 0,73 & & & \\
\hline \multirow{3}{*}{$\begin{array}{l}\text { Kültürel Eğlence } \\
\text { Aktiviteleri }\end{array}$} & yetersiz & 222 & 2,29 & 0,72 & \multirow{3}{*}{4,872} & \multirow{3}{*}{, $008^{*}$} & $1<3$ \\
\hline & normal & 154 & 2,41 & 0,65 & & & \\
\hline & yeterli & 140 & 2,53 & 0,82 & & & \\
\hline \multirow{3}{*}{$\begin{array}{l}\text { Ev Merkezli Sosyal } \\
\text { Aktiviteler }\end{array}$} & yetersiz & 222 & 3,18 & 0,60 & \multirow{3}{*}{0,679} & \multirow{3}{*}{, 508} & \\
\hline & normal & 154 & 3,16 & 0,70 & & & \\
\hline & yeterli & 140 & 3,25 & 0,76 & & & \\
\hline \multirow{3}{*}{ Sosyal Aktiviteler } & yetersiz & 222 & 1,79 & 0,78 & \multirow{3}{*}{11,735} & \multirow{3}{*}{, $000^{*}$} & $1<2$ \\
\hline & normal & 154 & 2,19 & 0,79 & & & $1<3$ \\
\hline & yeterli & 140 & 2,14 & 1,05 & & & \\
\hline
\end{tabular}

${ }^{*} p<0,05$

Öğrencilerin haftalık sahip olunan boş zaman süresi açısından boş zaman katılım seviyeleri incelendiğinde, açık alan aktivitelerine, spor aktivitelerine, hobiler ve açık alan aktivitelerine, kültürel eğlence aktivitelerine, sosyal aktivitelere katılımlarında anlamlı bir farklılığın olduğu saptanmıştır $(\mathrm{p}<0,05)$. Ortalama puanlar incelendiğinde yeterli bulanların açık alan aktivitelerine, spor aktivitelerine, hobiler ve açık alan aktivitelerine, kültürel eğlence aktivitelerine katılım düzeylerinin en büyük iken yetersiz bulanların ortalaması en küçük, normal bulanların sosyal aktivitelere katılım düzeyileri en büyük iken yetersiz bulanların ortalaması en küçük olduğu tespit edilmiştir. Öğrencilerin haftalık sahip olunan boş zaman süresi açısından algılanan wellness düzeyleri incelendiğinde, manevi ve entelektüel wellness alt boyutlarında anlamlı farklılık bulunmaktadır $(p<0,05)$. Ortalama puanlar incelendiğinde haftalık sahip olunan boş zaman süresini yeterli olarak değerlendiren öğrencilerin manevi wellness düzeyleri en büyük iken yetersiz bulanların en küçük olduğu ve haftalık sahip olunan boş zaman süresini normal olarak değerlendiren öğrencilerin entelektüel wellness düzeyleri en büyük iken yetersiz bulanların ortalamasının ise en küçük olduğu tespit edilmiştir.

Süzer (2000) çalışmasında, üniversite öğrencilerinin boş zamanlarını, dağılım içinde en yüksek oranda (\%62.3), açık hava, park bahçe vb. yerlerde geçirmeyi tercih ettiklerini; Somuncu ve arkadaşlarının (2015), Ankara'daki üniversite öğrencilerinin boş zaman etkinliklerine katılabilmek için yeterli boş zamana sahip olduğunu ayrıca cinsiyet ve gelirin boş zamanın değerlendirilmesini etkilediğini, öğrenciler boş zamanlarında 
müzik dinleme, spor yapma, kitap ve gazete okuma, sinemaya gitme, fuar ve parkları gezme, arkadaş ziyareti, ve televizyon izleme gibi etkinlikleri tercih ettiklerini; Sanghee ve arkadaşlarının (2012), zorunlu toplum hizmetlerinin hem de sivil faaliyetlere gönüllü katılımın, üniversite öğrencilerinin yaşamlarında kişisel gelişimlerine yardımcı olabileceğini ayrıca gönüllü sivil faaliyetlere katılımın ve boş zaman memnuniyetinin strese bağlı büyümeyle olumlu yönde ilişkili olduğunu tespit etmiştir.

Tablo 11.Algılanan Wellness ve Boş Zaman Katılım Arasındaki İlişkinin İncelenmesi

\begin{tabular}{|c|c|c|c|c|c|c|c|}
\hline & & $\begin{array}{l}\text { Açık Alan } \\
\text { Aktiviteleri }\end{array}$ & $\begin{array}{l}\text { Spor } \\
\text { Aktiviteleri }\end{array}$ & $\begin{array}{l}\text { Hobiler ve } \\
\text { Açık Alan } \\
\text { Aktiviteleri }\end{array}$ & $\begin{array}{l}\text { Kültürel } \\
\text { Eğlence } \\
\text { Aktiviteleri }\end{array}$ & $\begin{array}{l}\text { Ev Merkezli } \\
\text { Sosyal } \\
\text { Aktiviteler }\end{array}$ & $\begin{array}{l}\text { Sosyal } \\
\text { Aktiviteler }\end{array}$ \\
\hline Psikolojik & $\mathrm{r}$ & ,077 & ,077 & $103^{*}$ & $130^{* *}$ & $138^{* *}$ & $103^{*}$ \\
\hline Wellness & $\mathrm{p}$ & 082 & 082 & 019 & ,003 & ,002 & 019 \\
\hline Duygusal & $\mathrm{r}$ & ,037 & ,012 & ,079 & ,076 & ,207 & ,075 \\
\hline Wellness & $\mathrm{p}$ & ,398 & 793 & ,072 & ,084 & ,000 & ,090 \\
\hline Sosyal & $\mathrm{r}$ &,- 047 & $-139^{* *}$ & -085 &,- 006 & $199^{* *}$ &,- 057 \\
\hline Wellness & $\mathrm{p}$ & 288 & ,002 & ,053 & 894 & , 000 & 195 \\
\hline Fiziksel & $\mathrm{r}$ & $103^{*}$ & , 077 &,- 018 & ,038 & $136^{* *}$ & $121^{* * *}$ \\
\hline Wellness & $\mathrm{p}$ & 019 & ,079 & 684 & ,386 & ,002 & ,006 \\
\hline Manevi & $\mathrm{r}$ &, 063 & ,014 & 083 & ,071 & $170^{* *}$ & $171^{* *}$ \\
\hline Wellness & $\mathrm{p}$ & 150 & 747 & ,061 & 107 & ,000 &, 000 \\
\hline Entelektüel & $\mathrm{r}$ & $105^{*}$ & ,044 & $146^{* *}$ & $139^{* *}$ & $138^{* *}$ & $135^{* *}$ \\
\hline Wellness & $p$ & ,017 & ,315 & , 001 & ,002 & ,002 &, 002 \\
\hline
\end{tabular}

${ }^{*} p<0,05 ;{ }^{* *} p<0,01$

Psikolojik wellness ile hobiler ve açık alan aktiviteleri arasında pozitif yönlü zayıf bir ilişki $(\mathrm{r}=0,103)$; kültürel eğlence aktiviteleri arasında pozitif yönlü zayıf bir ilişki $(\mathrm{r}=0,130)$; ev merkezli sosyal aktiviteler arasında pozitif yönlü zayıf bir ilişki $(r=0,138)$; sosyal aktiviteler arasında pozitif yönlü zayıf bir ilişki $(r=0,103)$ bulunmaktadır. Duygusal wellness ile ev merkezli sosyal aktiviteler arasında pozitif yönlü zayıf bir ilişki $(r=0,207)$ bulunmaktadır. Sosyal wellness ile spor aktiviteleri arasında negatif yönlü zayıf bir ilişki $(\mathrm{r}=-0,139)$; ev merkezli sosyal aktiviteler arasında pozitif yönlü zayıf bir ilişki $(r=0,199)$ bulunmaktadır. Fiziksel wellness ile açık alan aktiviteleri arasında pozitif yönlü zayıf bir ilişki (r=0,103); ev merkezli sosyal aktiviteler arasında pozitif yönlü zayıf bir ilişki $(\mathrm{r}=0,136)$; sosyal aktiviteler arasında pozitif yönlü zayıf bir ilişki $(r=0,121)$ bulunmaktadır. Manevi wellness ile ev merkezli sosyal aktiviteler arasında pozitif yönlü zayıf bir ilişki $(\mathrm{r}=0,170)$; sosyal aktiviteler arasında pozitif yönlü zayıf bir ilişki $(r=0,171)$ bulunmaktadır. Entelektüel wellness ile 
açık alan aktiviteleri arasında pozitif yönlü zayıf bir ilişki $(\mathrm{r}=0,105)$; hobiler ve açık alan aktiviteleri arasında pozitif yönlü zayıf bir ilişki $(\mathrm{r}=0,146)$; kültürel eğlence aktiviteleri arasında pozitif yönlü zayıf bir ilişki $(\mathrm{r}=0,139)$; ev merkezli sosyal aktiviteler arasında pozitif yönlü zayıf bir ilişki $(\mathrm{r}=0,138)$; sosyal aktiviteler arasında pozitif yönlü zayıf bir ilişki $(\mathrm{r}=0,135)$ bulunmaktadır.

\section{Sonuç ve Öneriler}

Çalışmada elde edilen bulgulara göre, boş zaman aktivitelerine katılım düzeylerinde demografik değişkenler açısından anlamlı farklılıklar bulunmaktadır. Cinsiyet, medeni durum, yaş, yaşanılan yer, öğrenim durumu, aylık toplam bütçe, kendine ayrılan süre ve haftalık sahip olunan boş zaman süresi açısından farklılık bulunmaktadır. Algılanan wellness düzeylerinde demografik değişkenler açısından anlamlı farklılık bulunmaktadır. Cinsiyet, medeni durum, yaş, yaşanılan yer, öğrenim durumu, aylık toplam bütçe ve haftalık sahip olunan boş zaman süresi açısından farklılık bulunmaktadır. Ayrıca, boş zaman aktivitelerine katılım ile alg1lanan wellness'in alt boyutları olan psikolojik, duygusal, sosyal, fiziksel, ruhsal ve entelektüel wellness ile pozitif bir korelasyona sahiptir.

Araştırmaya paralel olarak alanyazında yapılan çalışmaların bazıları şöyledir;

Chaplin, Thomas ve Voyle (1992) boş zaman aktivitelerini tercih etmede sosyalleşme olasılıklarının daha yüksek olduğunu; Schechtman ve Ory (2001) ile Tsai (2004) araştırmalarında egzersizin duygusal wellness ve yaşam kalitesini iyileştirmede önemli bir faktör olduğunu, öğrencilerin sınav kaygısından kaynaklı daha çok ev merkezli sosyal etkinliklere katılımı ön plana çıktığını; Tsai (2004), boş zaman katılımı ve sosyal wellness arasında anlamlı ilişki olduğunu; Penedo ve Dahn (2005) ile Doğan (2006) düzenli fiziksel aktiviteye katılanların yaşam kalitelerinin, zihinsel ve fiziksel sağlıklarının daha iyi sağlık sonuçları gösterdiğini ve fiziksel aktivitenin esenlik halini etkileyen önemli bir faktör olduğunu; Abdulhayoğlu, Kaya ve Konar (2012), entelektüel wellness ve yoğunlaştırılmış tüm aktivitelerde sporcunun wellness boyutu yüksek çıkarken, bilgi, araştırma ya da entelektüel etkinlik seviyelerinde orta seviyede dağılım gösterdiğini; Güler (2010)'e göre Yoga eğitim süresi ve esenlik 
algısı incelendiğinde wellness algısından hoşnut ve oldukça hoşnut olanların Yoga eğitim süresi arttıkça memnuniyetlerinin arttığı, yanı sıra Yoga eğitiminin wellness kalitesindeki tüm alanlarla ilişkili olduğu; duygusal, spiritüel, psikolojik ve entelektüel alanlar arasında da güçlü bir ilişki olduğunu; Tsai (2004) ve Güler (2017) araştırmalarında rekreasyonel aktivitelerle ile wellness arasındaki ilişkinin bu çalışmada olduğu gibi pozitif yönlü olduğunu; Doğan (2018), çalışmasında öğrencilerin rekreasyonel aktivitelerden fiziksel, psikolojik ve sosyal açıdan yuiksek bir rekreasyon fayda düzeyi elde ettiğini tespit etmiştir.

Sonuç olarak, bireylerin wellness düzeylerinin arttırılması için aktif ve düzenli boş zaman aktivitelerine katılımları gerekmektedir. Boş zaman aktivitelerinin yaşam biçimine dönüştürülmesi, sürdürülebilir yüksek bir wellness halini desteklemesi ve kişisel performansı yükseltmesinin yanı sıra eğitim sonrası iş-yaşam dengesinin sağlanmasında öğrenciler için önemli bir faktördür. Bu bağlamda stres, sınav ve iş kaygısı içinde olan öğrencilerin rekreatif faaliyet alışkanlıklarının detaylı ve bireysel olarak incelenmesi ve rehberlik hizmetlerinin sunulması önemli katkı sağlayacaktır. Öğrencilerin zaman kısıtlaması ve gelir düzeyleri göz önüne alınarak yaşam kalitesini artırmaya yönelik uygulanacak politikalarda, günümüz şartlarına ve teknolojisine uygun, sağllklı, yeterli, güvenlikli rekreasyon programlarının oluşturulması ve daha etkili organize edilmesi gerekmektedir. Bu durum öğrencilerin yaşadığ1 mekân ve sosyal çevresi ile ilişkilerinin dengeli bir şekilde gelişimine, kişisel kabiliyetlerini keşfetmelerine, boş zaman aktivitelerine ilişkin olumlu tutum geliştirmelerine ve wellness düzeylerinin artmasına imkân sağlayacaktır.

Araştırma sonunda alan yazına kaynaklık etmesi açısından bazı öneriler geliştirilmiştir.

- Öğrencilerin cinsiyet durumlarına göre boş zaman aktivitelerine katılımları incelendiğinde, erkek öğrencilerin kadın öğrencilere göre spor yapmaya daha eğimli oldukları tespit edilmiş ve erkek öğrencilerin duygusal, fiziksel ve manevi wellness düzeylerinin daha büyük olduğu belirlenmiş̧tir. Bu bağlamda kadın öğrencilerin boş zaman aktivitelerine katılımlarını sağlamak adına "Herkes için spor" etkinliklerinin artırılması ve daha etkili organize edilmesi önerilmektedir. 
- Genç nüfus oranının yüksek olduğu ülkemizde daha erken yaşlarda boş zaman aktivilerine katılım düzeyini artıracak rekreatif faaliyetler düzenlenmelidir.

- Çalışmamda bekar katılımcı sayısı evli katılımcı sayısına oranla oldukça yüksektir. Bu konuda bir sonraki çalışmada örneklemde evli katılımcı sayısının arttırılmasına yönelik düzenlemeler yapılabilir.

- Öğrencilerin sınav kaygısından kaynaklı boş zaman aktivitelerine katılım konusunda farkındalık düzeyleri ve motivasyonlarını yükseltmeye ilişkin eğitim faaliyetleri yürütülebilir. Ders programları ve günlük zaman çizelgeleri hazırlanırken öğrencilerin boş zaman sürelerini artırıcı önlemler alınmalıdır.

- Boş zaman aktivitelerine katılım, öğrencilerin başarı seviyesini artırmada, wellness düzeylerini ve yaşam kalitesini iyileştirmede önemli bir etken olduğundan, öğrencilerin boş zamanlarını değerlendirebilecekleri alanlar geliştirilmelidir.

- Öğrencilerin yaşam kalitesini artıracak faaliyetler geliştirilirken, öğrencilerin gelir durumlarının da boş zaman aktivitelerine katılım düzeylerini etkileyen önemli bir faktör olduğu göz önünde bulundurulmalıdır. Öğrencilerin boş zaman aktivitelerini keşfetmeleri ve katılımları sağlamak için fırsat eşitliği sağlanmalıdır.

- Öğrencilerin yaşadıkları yer bakımından, boş zaman aktivitelerine katılımları değişkenlik gösterdiğinden yerel yönetimler bünyesindeki sağlıklı yaşam ve spor merkezleri ile görüş birliğine varılmalı ve toplumun her kesimine sunulan etkinliklerin kapsam ve içeriği geliştirilmelidir.

- Algılanan wellness düzeyinin daha da arttırılması için çalışmalar yapılabilir. Bunun için özellikle öğrencilerin düzenli olarak spor yapmalarını ve fiziksel aktiviteye ilişkin olumlu tutum geliştirilmelerini sağlayacak ortamlar oluşturulmalıdır.

- Algılanan wellness'ın her boyutu arasındaki ilişkileri ve anlamı keşfetmek için karma bir metodoloji de kullanılabilir.

- Literatürdeki bazı çalışmaların bulgularıyla karşılaştırıldığında, araştırma sonuçları benzerlikler ve farklılıklar göstermektedir. Bu nedenle yeni yapılacak çalışmalar daha geniş katılımlı ve farklı örneklem gruplarından oluşan çalışmaların yapılması önerilmektedir. 
EXTENDED ABSTRACT

\title{
The Relationship between Leisure Activities Participation and Perceived Wellness
}

\author{
Özlem Gürsoy-Halise Dilek Sevin \\ Gazi University
}

Etymologically, the concept of leisure is formed from the combination of the Greek words "skhole" and the Latin "licere" and is expressed with the English word "leisure". While the Greek word skhole is associated with learning and culture in the sense of being exempt from work and obligations, the Latin word licere generally means to be on leave or to be free (Blackshaw, 2010, p.4-5). Leisure is the time that is outside of the essential needs of the person, does not work and can spend it on his own will (Kılbaş, 2001, p.28). Leisure time is the work and occupation that the individual chooses to have fun, to relax, to improve his/her nonvocational education, to increase his relations with the society or to join the society voluntarily after performing his family, social and professional duties. Wasted time in leisure activities should not result in worthless pursuits and should not be abused. For this reason, leisure time evaluation should be done carefully and cautiously. Therefore, leisure time supports and facilitates change by providing new opportunities to the individual (Edginton, 2007).

The concept used as "wellness" in English corresponds to the meanings of vitality, physical harmony (fitness), well-being in Turkish. These different concepts were translated into Turkish as "well-being" and used in this way in most studies (Karagözoğlu, 2005: 10). wellness; It is the state of being healthy in harmony of body, mind and intellect. While Dunn describes wellness as "well-being is a life process in the effort to continue to improve physical and psychological well-being," Dr. Donald Ardell, on the other hand, stated that it consists of personal responsibility, conscious nutrition, physical fitness, stress management and environmental awareness (Ardell, 1977, p.324).

The perceived wellness model developed by Adams, Bezner, and Steinhardt (1997) provides a holistic conceptualization of how 
individuals can achieve optimal wellness. Adams et al. define wellness as a way of life that allows for the consistent and balanced development of the physical, spiritual, psychological, social, emotional and intellectual dimensions of human existence. physical size; It covers positive perceptions and expectations about the physical health of the person. Emotional dimension; It represents one's self-confidence, that is, selfesteem. Psychological dimension; individual's optimism and positive expectations about life. Social dimension; characterized by the fact that the person receives social support at the same time as the social service provider. spiritual dimension; positive perceptions about the meaning of life and the effort to live with a purpose. Finally, the intellectual dimension; It can be defined as having optimal intellectual activity to stimulate mental activity (Adams et al., 1997).

The aim of the research is to determine how senior and university graduate students spend their free time, to determine the relationship between their participation in leisure activities and wellness, and to reveal students' perceptions of wellness dimensions.

The sample of the study was formed based on the random sampling method. The population of the research consists of 3,298 students enrolled in 13 educational institutions that offer courses within the scope of KPSS-A Group on the basis of Ankara province Çankaya district. According to the sample calculation made, it is sufficient to conduct a survey on at least 344 students. However, in order to minimize the margin of error and increase the level of reliability, 516 students were determined as a sample group.

The analysis of the data was done with the SPSS program and it was studied with a confidence level of $95 \%$. Since the skewness and kurtosis values of the scale scores were between -3 and +3 , it was determined that they were suitable for normal distribution. The scale was analyzed with $t$ and ANOVA tests, which are parametric test techniques that differ according to demographic variables. Tukey test was used for multiple comparison in case of difference in ANOVA test. The relationship between the scale scores was analyzed with the Pearson correlation test.

In this study; There are significant differences in the level of participation in leisure activities in terms of demographic variables $(p<0.05)$. When the leisure time participation levels of the students are 
examined, according to their gender, it is found that the participation levels in outdoor activities, sports activities and social activities in men, and in hobbies and outdoor activities and cultural entertainment activities in women are higher; According to their marital status, the level of participation in sports activities, hobbies and outdoor activities is higher in those who are single, and the level of participation in homecentered social activities in those who are married; According to age groups, the average score of those aged 24-26 in terms of sports activities is the highest, while the average of those aged 27 and over is the lowest; In terms of the place where they spend most of their lives, the level of participation in cultural entertainment activities is the highest, and the average of those who have spent the majority of their lives in the villagetown is the lowest; According to their educational status, the level of participation in social activities of graduates and senior students is higher; In terms of monthly total budget, while the average score of those with a budget of $751 \mathrm{TL}-1250 \mathrm{TL}$ for sports activities participation levels is the highest, the average of those with $250 \mathrm{TL}-750 \mathrm{TL}$ is the lowest; In terms of weekly leisure time, those who find it sufficient have the highest level of participation in outdoor activities, sports activities, hobbies and outdoor activities and cultural entertainment activities, while the average of those who find it insufficient is the smallest, while those who find it normal have the highest participation levels in social activities. average was found to be the smallest. The $\mathrm{H}_{1}$ hypothesis was partially accepted.

There is a significant difference in perceived wellness levels in terms of demographic variables $(p<0.05)$. When the perceived wellness levels of the students were examined, it was found that physical, emotional and spiritual wellness participation levels were higher in males according to their gender status; According to their marital status, those who are married have higher spiritual and intellectual wellness levels; According to age groups, while the average score of those aged 27 and over is the highest in physical and intellectual wellness levels, the average decreases as age decreases, and in terms of where they spend most of their lives, those who have spent most of their lives in metropolitan areas have the highest emotional, social, spiritual and intellectual wellness levels, the average of those who have lived in the village-town is the smallest; 
According to their educational status, the emotional, social and intellectual wellness levels of the graduates are higher; In terms of monthly total budget, those with a psychological wellness budget of 751 TL - 1250 TL had the highest average score, while those with $250 \mathrm{TL}-750$ TL had the lowest average; In terms of weekly leisure time, it was determined that while the spiritual wellness level of those who find it sufficient is the highest, the average of those who find it insufficient is the lowest, and those who find it normal have the highest intellectual wellness levels, while the average of those who find it insufficient is the lowest. The $\mathrm{H}_{2}$ hypothesis was partially accepted.

Participation in leisure activities is positively correlated with psychological, emotional, social, physical, spiritual and intellectual wellness in all dimensions. There is a weak positive correlation between psychological wellness and hobbies and outdoor activities ( $\mathrm{r}=0.103)$, cultural entertainment activities $(\mathrm{r}=0.130)$, home-centered social activities $(\mathrm{r}=0.138)$, and social activities $(\mathrm{r}=0.103)$. There is a weak positive correlation between emotional wellness and home-centered social activities $(r=0.207)$. There is a weak negative relationship between social wellness and sports activities $(\mathrm{r}=-0.139)$, and a weak positive relationship between home-centered social activities $(\mathrm{r}=0.199)$. There is a weak positive correlation between physical wellness and outdoor activities $(\mathrm{r}=0.103)$, home-centered social activities $(\mathrm{r}=0.136)$, social activities $(\mathrm{r}=0.121)$. There is a weak positive correlation between spiritual wellness and home-centered social activities $(\mathrm{r}=0.170)$ and social activities $(\mathrm{r}=0.171)$. Between intellectual wellness and outdoor activities $(\mathrm{r}=0.105)$, hobbies and outdoor activities ( $\mathrm{r}=0.146)$, cultural entertainment activities $(\mathrm{r}=0.139)$, home-centered social activities $(\mathrm{r}=0.138)$, social activities $(\mathrm{r}=0.135)$ There is a weak positive relationship. The $\mathrm{H}_{3}$ hypothesis was partially accepted.

As a result, students' participation in home-based and social activities comes to the fore in line with professional goal setting, exam-oriented lifestyles and economic conditions. Participation in home-centered and social activities created a positive relationship with all sub-dimensions of wellness. In this case, it affects their psychological well-being without strenuous activities, their ability to cope with symptoms such as 
depression and stress by getting support from their family and friends, and their healthy communication.

The tendency of students to participate in civic activities, outdoor activities, hobbies and outdoor activities, cultural activities and entertainment has created a positive relationship with psychological, social, physical, spiritual and intellectual levels. In this case, the cultural values and attitudes of the students, the sense of curiosity and determination of the direction in life, the desire to get rid of the pressure of daily life and to stay fit, regular nutrition, getting enough sleep, internal values, beliefs and experiences increase their participation in cultural and social activities that will positively affect them.

\section{Kaynakça / References}

Abdulhayoğlu, B., Kaya, B. ve Konar, N. (2012). Masa tenisi oyuncularının esenlik algıları. Selçuk Üniversitesi Beden Eğitimi ve Spor Bilim Dergisi, 14(2), 268-272.

Adams, T., Bezner, J. and Steinhardt, M. (1997). The conceptualization and measurement of perceived wellness: Integrating balance across and within dimensions. American Journal of Health Promotion, 11(3), 208-218.

Ardahan, F. ve Yerlisu Lapa, T. (2010). Üniversite öğrencilerinin serbest zaman tatmin düzeylerinin cinsiyete ve gelire göre incelenmesi. Spor Bilimleri Dergisi, 21(4), 129-136.

Ardahan, F., Turgut, T. ve Kalkan, A. K. (2016). Her yönüyle rekreasyon. Ankara: Detay Yayıncilik.

Ardell, D. B. (1977). High level wellness strategeis. Health Education, 324.

Arslan, H. (2014). Üniversite öğrencilerinin boş zaman değerlendirme tercihleri: Çankırı Karatekin Üniversitesi örneği. Dumlupmar Üniversitesi Sosyal Bilimler Dergisi, 40, 193-208.

Baştürk, S., ve Taştepe, M. (2013). Evren ve örneklem. S. Baştürk (Ed.), Bilimsel Araştırma Yöntemleri (s.129- 159). Ankara. Vize Yayıncıllk, 139.

Blackshaw, T. (2010). Leisure. 1. Bask1, London: Routledge, 4-5.

Bull, C., Hoose, J. and Wheet, M. (2003). AnIntroduction to leisure studies. New York: Prentice Hall, p.73.

Chandler, C.K., Holden, J.M. and Kolander, C.A. (1992). Counseling for spiritual wellness: Theory and practice.Journal of Counseling and Development, 71, 168175. 
Chaplin, L., Thomas, D. and Voyle, J. (1992). Sport, recreation and well-being. D. Thomas A. Veno (Eds) Psychology and Social Change Dunmore Press Palmerston North, NZ 132-156.

Cummins, R. A. (2000). Personal income and subjective well-being: A review. Journal of Happiness Studies, 1, 133-158.

Çakıcı, Z. (2010). Esenlik ve akademik tükenmişlik ilişkisi: İstanbul'daki Vakıf Üniversiteleri üzerine bir araştırma.Yayınlanmamış Yuiksek Lisans Tezi. Marmara Üniversitesi, Sosyal Bilimler Enstitüsü, İstanbul.

Dierksen, F. W. (2005). Welness of Kansas Principals: Self perception. Yayımlanmamış Doktora Tezi. Wichita State Üniversitesi, Kansas.

Doğan, T. (2006). Üniversite öğrencilerinin iyilik halinin incelenmesi. H.Ü. Ĕ̆itim Fakültesi Dergisi, 30, 120-129.

Doğan, M. N. (2018). Hukuk fakultesi öğrencilerinin rekreasyonel aktivitelerden elde ettikleri faydalarn ve mutluluk düzeylerinin incelenmesi. Yayınlanmamış Yüksek Lisans Tezi. Gazi Üniversitesi Sağllk Bilimleri Enstitüsü, Ankara.

Dunn, H.L. (1961). High level wellness.Arlington, VA: Beatty Press, United States, 240.

Edginton, C. R. (2007). The World Leisure Organization: Promoting social, cultural and economic transformation. Licere, Belo Horizonte, 10(2),115.

Enochs, W. (2001).Wellness and adjustment to college based on type of residence hall and gender.Yayımlanmamış Doktora Tezi. Arkansas Üniversitesi.

Ergül, O. K. (2008). Üniversite gençliğinin sportif rekreasyon etkinliklerine yönelik ilgileri ve katılma düzeylerinin belirlenmesi. Yayımlanmamış Yuiksek Lisans Tezi. Celal Bayar Üniversitesi Sağlık Bilimleri Enstitüsü, Manisa.

Eruzun, C. (2017). Kadmlarm spor etkinliklerine katıllmlarmmn boş zaman tatmini ve yaşam kalitesine etkilerinin araştırlmasl: B-Fit Spor Merkezleri üyeleri örneği.Yayımlanmamış Yuiksek Lisans Tezi. Bartın Üniversitesi Eğitim Bilimleri Enstitüsü, Bartın.

Garrity, T. E, Somes, G. W. and Marx, M. B. (1978). Factors Influencing SelfAssessment of Health. Soe. Sci. Med., 12, 77-81.

Güler, H. (2017). Beden Eğitimi ve Spor Yüksekokullarnnda Öğrenim gören öğrencilerin boş zaman engellerinin boş zaman motivasyonlarına etkisinin araştırlması (Bartın Üniversitesi Örneği). Yayımlanmamış Yüksek Lisans Tezi. Bartın Üniversitesi Eğitim Bilimleri Enstitüsü, Bartn.

Güler, M. M. (2010). Yoga egzersizlerinin, çalı̧anlarda esenlik ve yaşam kalitesi üzerindeki etkisi. Yayımlanmamış Yüksek Lisans Tezi. Marmara Üniversitesi Sağlık Bilimleri Enstitüsü, İstanbul. 
Haug, C. V. (1991). Gesundheitsbildung im Wandel. Bad Heilbrunn, 428.

Kafkas, M. E., Kafkas, Ş. A. and Acet, M. (2012). Beden eğitimi öğretmenlerinin sağlıklı yaşam biçimi davranış düzeylerinin incelenmesi. Dumlupınar Üniversitesi Sosyal Bilimler Dergisi, 32(2), 47-56.

Kaplan, G. A. and Camacho, T. (1983). Perceived health and mortality: A nine-year follow-up of the human population laboratory cohort. Am. J. Epidemiol., 117, 292-304.

Karagözoğlu, C. (2005). Sporda psikolojik destek. İstanbul: Morpa Yayınları, 10.

Karaküçük, S. (1999). Rekreasyon boş zamanları değerlendirme. (Üçüncü Baskı). Ankara: Bağırgan Yayınevi. 6-128.

Karaküçük, S. (2008).Rekreasyon: Boş zaman değerlendirme. Altıncı Baskı. Ankara: Gazi Kitabevi, 14-66.

Karaküçük, S. (2016). Rekreasyon bilimi. Birinci Baskı. Ankara: Gazi Kitabevi, 562-563.

Karaküçük, S. ve Akgül, B. M. (2016).Ekorekreasyon: Rekreasyon ve çevre. Birinci Baskı. Ankara: Gazi Kitabevi, 5-88.

Kılbaş, Ş. (2001). Rekreasyon. Birinci Baskı. Adana: Anaca Yayınları, 28.

Kim, O. A., Oh, J. W., Kim, Y. S., Kim, H. W., Lee, M. Y. and Ha, S. H. (2014). Impacts of Perceived Health Status and Self-Efficiacy in Hospital Nurses on Their Health Promoting Behaviors.Advanced in Information Sciences and Service Sciences, 6(1), 139-144.

Lengfelder, J. R. (1987). Leisure wellness and time management: Is there a connection? College Student Journal, 21(2), 180-183.

Marshall, G. (1999). Sosyoloji sözlü̈̆̈̈̈. (Çev. O. Akınhay ve D. Kömürcü). Ankara: Bilim ve Sanat Yayınları, 689.

Mehmedoğlu, A. U. (2004). Kişilik ve din.İstanbul: Değerler Eğitimi Merkezi Yayınları.

Memnun, S. (2006). Algılanan Esenlik Ölçeğinin (Perceived Wellness Scale) geçerlilik ve güvenilirlik çalışması ve beden eğitimi öğretmenlerinin esenlik algıları. Yayınlanmamış Yüksek Lisans Tezi. Marmara Üniversitesi, Eğitim Bilimleri Enstitüsü, İstanbul.

Myers, J. E. and Degges-White, S. (2007). Aging well in an upscale retirement community: The relationships among perceived stress, mattering, and wellness. Adultspan Journal, 6(2), 96-110.

Myers, J. E. and Williard, K. (2003). Integrating Spirituality into counseling and counselor training: A developmental, wellness approach. Counseling $\mathcal{E}$ Values, 47(2), 145-146. 
Önal, L. (2017). Atatürk Üniversitesi öğrencilerinin boş zaman tutumlar ile boş zaman aktivitelerine katılımın engelleyen faktörlerin incelenmesi. Yayınlanmamış Yüksek Lisans Tezi. Atatürk Üniversitesi Sosyal Bilimler Enstitüsü, Erzurum.

Öztürk, H. (2013). Sanayi çalışanlarmmn rekreatif aktivitelere katılımlarmın örgütsel bağlllk ve tükenmişlik düzeylerine etkisi (Gaziantep Uygulaması). Yayınlanmamış Doktora Tezi. Gazi Üniversitesi Sağlık Bilimleri Enstitüsü, Ankara.

Penedo, F. J. and Dahn, J. R. (2005).Exercise and well-being: A review of mental and physical health benefits associated with physical activity. Current Opinion in Psychiatry, 18(2), 189-193.

Richards, M., Hardy, R. and Wadsworth, M. E. (2003). Does active leisure protect cognition? Evidence from a national birth cohort. Social Science \& Medicine, 56(4), 785-792.

Sanghee, C.,Youngkhill, L., Byunggook, K. and Jinmoo, H. (2012). The contribution of leisure participation and leisure satisfaction to stress-related growth. Leisure Sciences, 34(5), 436-449.

Schechtman, K. B. and Ory, M. G. (2001).The effects of exercise on the quality of life of frail older adults: A preplanned meta-analysis of the FICSIT trials. Annals of Behavioral Medicine, 23(3), 186-197.

Sevin, H. D. ve Barakazı, E. (2018). Boş zaman, sağlık, esenlik (Wellness) ve yaşam kalitesi. İçinde B. Gülcan ve G. Sağlam Arı (Editörler). Çok Disiplinli Çalışmalar. Birinci Baskı, Ankara: Detay Yayınları, 296-311.

Somuncu, M., Gültekin, A. S. ve Ceylan, S. (2015). Ankara'daki üniversite öğrencilerinin rekreasyon eğilimlerinin saptanması. 3. Rekreasyon Araştırmaları, Eskişehir: Anadolu Üniversitesi Kongresi Bildiri Kitabı, 304-316.

Steward, J. L. (1998). Reliability and ty of the Testwell: Wellness inventory-the organizational context of burnout. Jhhsa Spring, 472- 489.

Süzer, M. (2000). Üniversite öğrencilerinin boş zamanlarını değerlendirme alışkanlıkları. Pamukkale Üniversitesi Eğitim Fakültesi Dergisi, 8(8), 123-133.

Şimşek, H., Öztoprak, D., İkizoğlu, E., Safalı, F., Yavuz, Ö., Onur, Ö., Tekel, Ş. ve Çiftçi, Ş. (2012). Tip fakültesi öğrencilerinde sağlıklı yaşam biçimi davranışları ve ilişkili etmenler. Dokuz Eylül Tip Fakültesi Dergisi, 26(3), 151-157.

Tavşancl, E. (2005). Tutumlarm ölçülmesi ve SPSS ile veri analizi. Ankara: Nobel Yayıncilik.

Terzioğlu, A. ve Yazıc, M. (2003). Üniversite öğrencilerinin boş zamanların değerlendirme anlayış ve alışkanlıkları (Atatürk Üniversitesi Örneği).Erzincan Ĕ̆itim Fakultesi Dergisi, 5(2), 1-31. 
Thrane, C. (2000). Men, women, and leisure time: Scandinavian evidence of gender inequality. Leisure Sciences, 22,109-120.

Tsai, C.Y. (2004). The Relationship Between Leisure Participation and Perceived Wellness among Taiwanese Adult Ages 55-75 Years. Yayımlanmamış Doktora Tezi. Incarnate Word Üniversitesi, Texas.

Türk Dil Kurumu (TDK). Büyük Türkçe Sözlük. 20 Şubat 2019 tarihinde http://www.tdk.gov.tr/index.php?option=com_bts\&arama=kelime\&guid=TDK.GT S.5cb08220578d48.60919583adresinden erişildi.

Türkçe Sözlük (1983). Yedinci Baskı. Ankara: Türk Dil Kurumu, 1340.

Türkkahraman, M. (2006). Toplum ve temel toplumsal kurumlar.Kurumlar Sosyolojisine Giriş. Ankara: Alp Yayınevi, 240.

Uysal, V. (2003). Türkiye'de dindarlk ve kadin.İstanbul: Çamlıca Yayınları.

Veblen, T. (1995). Aylak Simffi. (Çev. İ. User). İstanbul: Marmara Üniversitesi Teknik Eğitim Fakültesi Matbaası, 38-87.

Vural, M. E. (2016). Yetişkinlerde alçakgönüllülük, dindarlı ve psikolojik iyi oluş ilişkisi. Yayınlanmamış Yüksek Lisans Tezi. Marmara Üniversitesi Sosyal Bilimler Enstitüsü, İstanbul.

Zimmer, Z. and Lin H. S. (1996). Leisure activityand well-being among the elderly in Taiwan: Testing hypotheses in an Asian setting. Journal of Cross-Cultural Gerontology, 11(2), 167-186.

Walton, E. and Takeuchi, D. (2010). Family structure, family processes, and wellbeing among asian americans: Considering gender and nativity. Journal of Family Issues, 31(3), 301-332.

\section{Kaynakça Bilgisi/Citation Information}

Gürsoy, Ö. ve Sevin, H. D. (2021). Boş Zaman Aktivitelerine Katılım ile Algılanan Wellness (Esenlik) İlişkisi. OPUS- Uluslararası Toplum Araştırmalarn Dergisi, 18(42), 5444-5479. DOI: 10.26466/opus.897041. 